\title{
DEVELOPMENT OF A SYSTEMWIDE PREDATOR CONTROL PROGRAM: STEPWISE IMPLEMENTATION OF A PREDATION INDEX, PREDATOR CONTROL FISHERIES, AND EVALUATION PLAN IN THE COLUMBIA RIVER BASIN
}

\author{
SECTION II: EVALUATION
}

\section{ANNUAL REPORT}

\author{
Prepared by: \\ Franklin R. Young \\ Columbia Basin Fish and Wildlife Authority \\ Portland, OR 97201 \\ In Cooperation With \\ Washington Department of Fish and Wildlife \\ Pacific States Marine Fisheries Commission \\ Columbia River Inter-tribal Fish Commission \\ Confederated Tribes of the Umatilla Indian Reservation \\ Nez Perce Tribe of Idaho \\ Yakama Indian Nation \\ Oregon Department of Fish and Wildlife
}

Prepared for:

U.S. Department of Energy

Bonneville Power Administration

Environment, Fish and Wildlife

P. 0. Box 3621

Portland, OR 97208-362 1

Project Number 90-077

Contract Number 94BI245 14

November 1997 
SECTION II. EVALUATION

\section{Cooperators}

Columbia Basin Fish and Wildlife Authority

Pacific States Marine Fisheries Commission

Oregon Department of Fish and Wildlife 


\section{Report E}

Development of a Systemwide Predator Control Program:

Indexing and Fisheries Evaluation

Prepared by

Thomas A. Friesen, Mark P. Zimmerman, and David L. Ward Oregon Department of Fish and Wildlife

Columbia River Research

17330 S.E. Evelyn Street

Clackamas, Oregon 97015

Report E -I 19 


\section{CONTENTS}

Page

ACKNOWLEDGMENTS . . . . . . . . . . . . . . . . . . . . 121

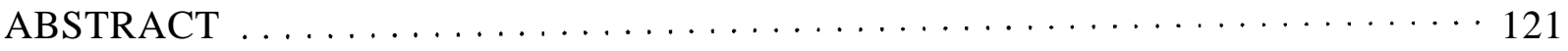

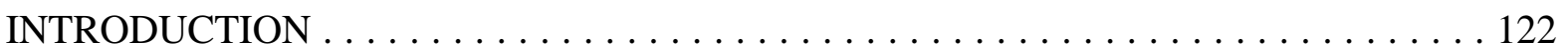

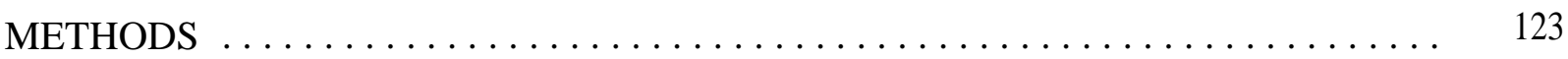

Fishery Evaluation and Loss Estimates $\ldots \ldots \ldots \ldots \ldots \ldots \ldots \ldots \ldots \ldots \ldots \ldots \ldots \ldots$

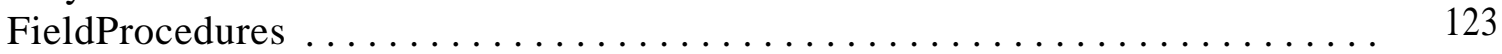

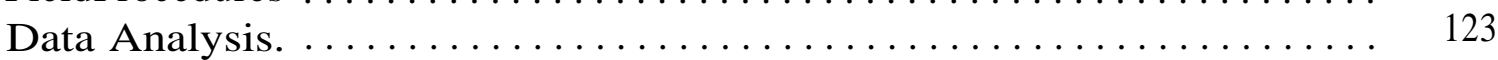

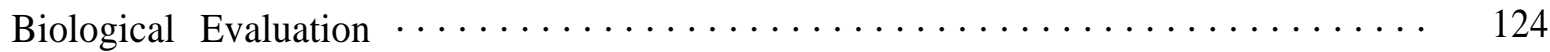

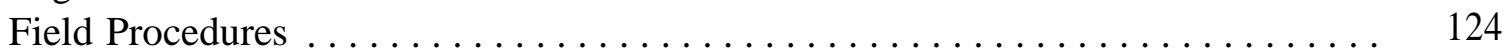

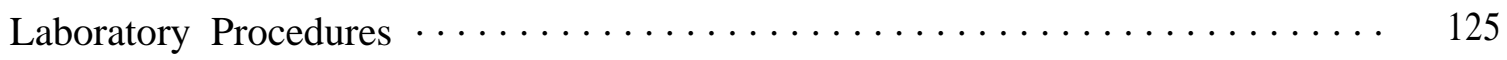

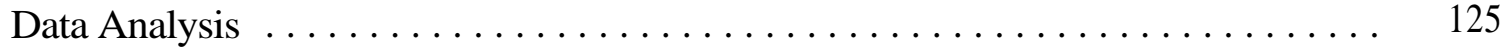

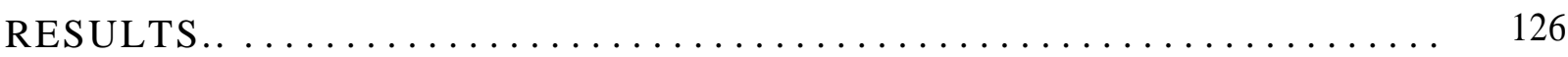

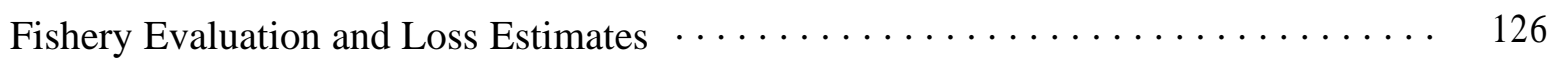

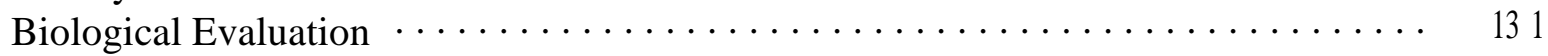

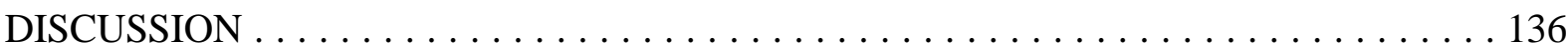

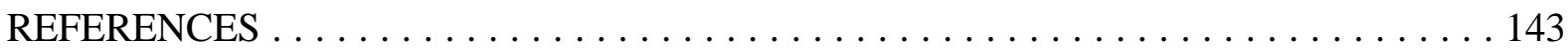

APPENDIX A. Exploitation of Northern Squawfish by Reservoir and Fishery,

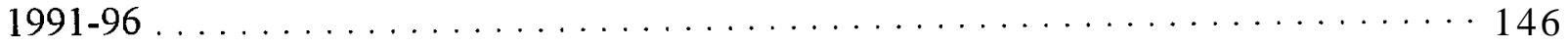

APPENDIX B. Density, Abundance, Consumption, and Predation Indices for Sampling Locations in the Lower Columbia and Snake Rivers, 1990-96 . . . . . . . . . 159

APPENDIX C. Timing of 1996 Consumption Index Sampling in Relation to Juvenile Salmonid Passage Indices at Lower Columbia and Snake River Dams . . . . . . 166

APPENDIX D. Digestive Tract Contents and Comparison of Fish Diets of Northern Squawfish, Smallmouth Bass, and Walleye in 1996 . 


\title{
ACKNOWLEDGMENTS
}

We are particularly grateful to project personnel that worked long hours in the field to collect the data presented in this report. Thanks to Travis Collier, Shawn Doan, Jennifer Harrington, Kevin Leader, Ken Kilwien, Tom Neill, Scott Neubig, George Reed, Vicki Royle, and Don Schluter.

This research was funded by the Bonneville Power Administration, John Skidmore, Project Manager (Contract DE-B 17 19-90BP07084). Kirk Beiningen of the Oregon Department of Fish and Wildlife, Frank Young of the Columbia Basin Fish and Wildlife Authority, and Russell Porter of the Pacific States Marine Fisheries Commission administered the contract and/or critically reviewed the manuscript.

We thank Thomas P. Poe and his staff (U.S. Geological Survey, Biological Resources Division), Ken Collis and his staff (Columbia River Inter-Tribal Fish Commission), and John Hisata and his staff (Washington Department of Fish and Wildlife) for their cooperation and help with project coordination. The U.S. Army Corps of Engineers (Corps) was very cooperative in the use of project facilities. We especially thank the following Corps personnel for help with coordination: Jim Kuskie, Miro Zyndol, Brad Eby, Bill Spurgeon, Tim Wik, Rex Baxter, and Bob Cordie.

\begin{abstract}
Predator control fisheries aimed at reducing predation on juvenile salmonids by northern squawfish Ptychocheilus oregonensis were implemented for the seventh consecutive year in the mainstem Columbia and Snake rivers. In this report, we (1) evaluate northern squawfish exploitation and size composition, and compare catch rate of incidentally-harvested fishes among the three major management fisheries in 1996, (2) estimate reductions in predation on juvenile salmonids since implementation of the fisheries, and (3) evaluate changes from 1990-96 in relative abundance, consumption, size and age structure, growth, and fecundity of northern squawfish.
\end{abstract}

Systemwide exploitation of northern squawfish $\geq 250 \mathrm{~mm}$ fork length was $12.1 \%$ for sportreward, $0.3 \%$ for dam-angling, and $0.5 \%$ for site-specific gill-net fisheries. Total exploitation was lowest in Lower Monumental Reservoir (0.0\%) and highest in McNary Reservoir (18.2\%). Mean fork length of harvested northern squawfish was $355 \mathrm{~mm}$ in the sport-reward, $391 \mathrm{~mm}$ in the damangling, and $408 \mathrm{~mm}$ in the gill-net fisheries. The dam-angling fishery had the lowest percentage (3.6\%) of incidental catch relative to the total number of fish caught. Incidental catch was $27.0 \%$ in the sport-reward fishery and $54.6 \%$ in the gill-net fishery.

If exploitation rates remain similar to mean 1991-96 levels, we estimate that potential predation by northern squawfish on juvenile salmonids in 1997 will be approximately $62 \%$ of 
predation levels prior to the implementation of removal fisheries. Further reductions in predation may be small, unless average exploitation in future years is higher than 1994-96 levels.

Relative abundance of northern squawfish declined slightly from 1995 in Bonneville Reservoir, Lower Monumental Dam tailrace, and Little Goose Dam tailrace. Mean abundance for 1994-96 was 48-60\% of 1990-93 levels among areas sampled at least five years. Indices of consumption were lower than 1995 in all areas except during summer in the tailrace boatrestricted zones of Bonneville and The Dalles dams. Predation indices have declined 69\% from pre- 1994 levels.

Decreases in proportional stock density were greater than could be explained by fluctuations in year-class strength, strongly suggesting that sustained removals may be altering the size structure of predator-sized northern squawfish. We found no evidence that northern squawfish have compensated in growth or fecundity in response to sustained exploitation.

\section{INTRODUCTION}

The goal of the Columbia River Northern Squawfish Management Program (NSMP) is to reduce mainstem mortality of juvenile salmonids attributed to predation by northern squawfish Ptychocheilus oregonensis. We established baseline levels of predation and described northern squawfish population characteristics prior to the implementation of sustained predator control fisheries by estimating northern squawfish abundance, consumption, and predation in Columbia River reservoirs (1990; Vigg et al. 1990), Snake River reservoirs (1991; Ward et al. 1993) and the unimpounded lower Columbia River downstream from Bonneville Dam (1992; Parker et al. 1994). We sampled Columbia River impoundments again in 1993 to evaluate changes from 1990 (Zimmerman et al. 1995). From 1994-96, we sampled in areas where sufficient numbers of northern squawfish could be collected to compare changes in predation among years (Knutsen et al. 1995; Zimmerman et al. in press). In this report we describe our activities and findings for 1996, and wherever possible, evaluate changes from previous years.

Our objectives in 1996 were to (1) evaluate the relative efficiency of each northern squawfish fishery by comparing exploitation rate, size composition, and incidental catch, (2) estimate reductions in predation on juvenile salmonids since the implementation of the NSMP, and (3) evaluate changes through 1996 in relative abundance, size structure, growth, and fecundity of northern squawfish in lower Columbia and Snake river reservoirs and in the Columbia River downstream from Bonneville Dam. 


\section{METHODS}

\section{Fishery Evaluation and Loss Estimates}

\section{Field Procedures}

Three northern squawfish fisheries were conducted in 1996. The sport-reward fishery was implemented by the Washington Department of Fish and Wildlife (WDFW) from April 29September 29 throughout the lower Columbia and Snake rivers. The dam-angling fishery was implemented by the Columbia River Inter-Tribal Fish Commission (CRITFC), Confederated Tribes of the Warm Springs Reservation of Oregon (CTWS), Confederated Tribes of the Umatilla Indian Reservation, Confederated Tribes and Bands of the Yakama Indian Nation (YIN), and the Nez Perce Tribe (NPT) from June 5- September 4 at Bonneville, The Dalles, John Day, McNary, Ice Harbor, Lower Monumental, Little Goose, and Lower Granite dams. A site-specific gill-net fishery was implemented by CRITFC, YIN, NPT, and CTWS from March 14-June 30 downstream from Bonneville Dam and in Bonneville, The Dalles, John Day, and McNary reservoirs.

We tagged and released northern squawfish to estimate exploitation rates for each fishery. We used electrofishing boats and gill nets to collect northern squawfish from March 25-June 20. We allocated equal sampling effort in all river kilometers (RKm) from RKm 71 through Priest Rapids Dam tailrace (RKm 639) on the lower Columbia River, and on the Snake River from the mouth through RKm 229, excluding Ice Harbor Reservoir. Northern squawfish greater than $240 \mathrm{~mm}$ fork length were tagged with a serially-numbered spaghetti tag and given a secondary mark (left pelvic fin clip). Tags were recovered from each fishery from April 22-September 29.

\section{Data Analysis}

We used mark-and-recapture data to compare exploitation rates of northern squawfish> 250 mm fork length among fisheries and reservoirs in 1996. Weekly estimates of exploitation for each fishery were calculated by dividing the number of tagged northern squawfish recovered by the number of tagged fish at large and summed to yield total exploitation rates (Beamesderfer et al. 1987). We also adjusted exploitation estimates for tag loss (4.2\%), determined by the recovery of secondary-marked fish without tags.

We calculated $95 \%$ confidence intervals for the number of tagged fish recovered each week. We calculated confidence intervals for variables distributed in a Poisson distribution from Ricker (1975) for weeks when tagging and fishing occurred simultaneously. After tagging was complete, we calculated confidence intervals using the formula

where

$$
\mathrm{m} \quad \pm 1.96 \sqrt{ } \mathrm{m} / \mathrm{n} \quad(\text { if } \mathrm{mn}>30)
$$

$\mathrm{n}=$ the number of sampling periods (weeks) remaining, and

$\mathrm{m}=$ the mean number of tagged fish recovered per week (Elliott 1977). 
Using this method, bounds were identical for all remaining weeks. We summed estimates for each week to give overall confidence limits.

We calculated mean fork length and compared length-frequency distributions among fisheries. We also compared incidental catch among fisheries for 1996 by determining the percent of the total catch composed of fish other than northern squawfish $\geq 250 \mathrm{~mm}$ fork length (incidental catch).

We used the "Loss Estimate Spreadsheet Model" (Zimmerman et al. 1995) to estimate predation on juvenile salmonids relative to predation prior to implementation of the NSMP. The model incorporates age-specific exploitation rates on northern squawfish and resulting changes in age structure to estimate changes in predation. We used a lo-year "average" age structure (based on catch curves) for a pre-exploitation base, and assumed constant recruitment. Age-specific consumption was incorporated; however, potential changes in consumption, growth, and fecundity due to removals were not considered likely. The model therefore estimates changes in potential predation related directly to removals. This in effect allows us to estimate the effects of removals if all variables except exploitation were held constant.

We estimated the potential relative predation in 1997 based on observed exploitation rates, and the eventual minimum potential predation assuming continuing exploitation at mean 199 1-96 levels. Because inputs to the model included three potential relationships between age of northern squawfish and consumption, and three estimates of exploitation (point estimate plus confidence limits), we computed nine estimates of relative predation for each year. We report the maximum, median, and minimum estimates.

\section{Biological Evaluation}

\section{Field Procedures}

To evaluate changes in relative abundance and consumption for northern squawfish, we used boat electrofishing to collect biological data from April 29-August 9 in the following areas: downstream from Bonneville Dam (RKm 117-121, RKm 171-177, and RKm 178-183), Bonneville Dam tailrace, Bonneville Reservoir, The Dalles Reservoir forebay, John Day Dam tailrace, John Day Reservoir, Little Goose Dam tailrace, Lower Granite Dam tailrace, and upper Lower Granite Reservoir (RKm 22 1-229). Sampling methods and gear specifications were as described in previous reports (Vigg et al. 1990; Ward et al. 1993; Parker et al. 1994; Zimmerman et al. 1995; Knutsen et al. 1995; Zimmerman et al. in press). Digestive tracts from all northern squawfish $\geq 250 \mathrm{~mm}$ fork length were preserved using methods described by Ward et al. (1995).

We collected biological data from all northern squawfish collected by electrofishing and from subsamples of fish harvested by the sport-reward and dam-angling fisheries to evaluate changes in population structure, growth, and reproduction. We determined fork length $(\mathrm{mm})$, total body weight (g), sex (male, female or undetermined), and maturity (undeveloped or immature, 
developing, ripe, or spent), and collected gonad (ripe females only) and scale samples. Fork length data for northern squawfish harvested by the site-specific gillnet fishery were provided by CRITFC.

\section{Laboratory Procedures}

We examined digestive tract contents of northern squawfish collected by electrofishing to measure relative consumption rates of juvenile salmonids by northern squawfish. Details of laboratory methods are given in Ward et al. (1995). We used scale samples from northern squawfish collected primarily by electrofishing for age determinations. We used gravimetric quantification (Bagenal 1968) to estimate fecundity of northern squawfish. Details of aging and fecundity procedures are given in Parker et al. (1995).

\section{Data Analysis}

We used catch per unit effort of standardized electrofishing runs as an index of northern squawfish density and calculated indices of northern squawfish abundance as the product of the northern squawfish density index and reservoir or area-specific surface area (Ward et al. 1995). We compared density and abundance indices from 1990-96 for all sampling areas.

The following formula was developed as a consumption index (CI) by Ward et al. (1995):

$$
\mathrm{CI}=0.0209 \mathrm{~T}^{1.60} \cdot \mathrm{MW}^{0.27} \cdot\left(\mathrm{s} \mathrm{GW}^{-0.61}\right)
$$

where $\quad \mathrm{T}=$ water temperature $\left({ }^{\circ} \mathrm{C}\right)$,

$\mathrm{MW}=$ mean predator weight $(\mathrm{g})$,

$\mathrm{S}=$ mean number of salmonids per predator, and

$\mathrm{GW}=$ mean gut weight $(\mathrm{g})$ per predator.

The consumption index is not a rigorous estimate of the number of juvenile salmonids eaten per day by an average northern squawfish; however, it is linearly related to the consumption rate of northern squawfish (Ward et al. 1995). Spring (May-June) and summer (July-September) consumption indices were compared from 1990-96 for all sampling areas. We used the product of abundance and consumption indices to calculate predation indices for spring and summer periods. We compared predation indices among years for reservoirs and areas where data had been collected each year. We plotted the daily juvenile salmonid passage index at lower Columbia and Snake River dams to compare timing of consumption index sampling with concentrations of juvenile salmonids present in each area.

Because fishery exploitation rates increase with size of northern squawfish (Zimmerman et al. 1995) sustained fisheries should decrease the abundance of large fish relative to the abundance of smaller fish. We used proportional stock density (PSD; Anderson 1980) where PSD $=100$ *(number of fish at least quality length / number of fish at least stock length) to compare size structure of northern squawfish populations among years in the Columbia River downstream from 
Bonneville Dam, Bonneville Reservoir, and John Day Reservoir. Stock and quality sizes for northern squawfish have been defined as 250 and $380 \mathrm{~mm}$ fork length, respectively (Beamesderfer and Rieman 1988; Parker et al. 1995).

Comparisons of PSDs among years may be biased by fluctuating year-class strengths that influence the number of stock-size fish (Mesa et al. 1990) and size-selectivity of sampling gear (Beamesderfer and Rieman 1988). To reduce bias, we used information on relative year-class strengths and natural mortality rates of northern squawfish to estimate PSDs that would be expected with and without program implementation and used size-selectivity of our sampling gear to adjust observed PSD estimates (Knutsen et al. 1995). We then compared observed and expected PSDs.

To evaluate changes in growth rate after implementation of the NSMP, we used observed length-at-age data for female northern squawfish from the Columbia River downstream from Bonneville Dam and Bonneville, John Day, and Lower Granite reservoirs. We determined regression parameters (slope and y-intercept) for fork length on age using only those ages where growth rate was linear (ages 5 through 14 downstream from Bonneville Dam and Bonneville Reservoir, ages 5 through 13 in John Day Reservoir, and ages 6 through 11 in Lower Granite Reservoir). We compared growth among years using joint $95 \%$ family confidence regions for estimates of parameter pairs (Neter et al. 1985). Parameter pairs were considered significantly different if point estimates (center-point of ellipse) were outside the confidence region for another year.

We calculated mean fecundity (number of developed eggs per female) and mean relative fecundity (number of developed eggs per gram of body weight) for northern squawfish from the Columbia River downstream from Bonneville Dam, and Bonneville, John Day, and Lower Granite reservoirs. We determined parameters for the regression of fecundity on fork length and compared relationships among years for each area using joint $95 \%$ family confidence regions for estimates of parameter pairs (Neter et al. 1985).

\section{RESULTS}

\section{Fishery Evaluation and Loss Estimates}

We tagged and released 1,430 northern squawfish throughout the lower Columbia and Snake rivers in 1996. A total of 162 tagged fish were recaptured in the three fisheries: 152 in the sport-reward fishery, four in the dam-angling fishery, and six in the site-specific gill-net fishery.

Total exploitation of northern squawfish in 1996 was $12.9 \%$, and ranged from $0.0 \%$ in Lower Monumental Reservoir to $18.2 \%$ in McNary Reservoir (Figure 1; Appendix A). Exploitation of northern squawfish by the sport-reward fishery was $12.1 \%$ in 1996 . Sport-reward exploitation increased from 1995 in Bonneville, The Dalles, Little Goose, and Lower Granite reservoirs, decreased downstream from Bonneville Dam, and did not change in John Day and Lower 
Monumental reservoirs (Figure 1; Appendix Table A-I). Dam-angling exploitation was 0.3\%, and 1996 exploitation rates declined in all areas except John Day Reservoir (Figure 1; Appendix Table A-2). Exploitation by the site-specific gill-net fishery totaled $0.5 \%$ and declined or remained the same in all areas (Figure 1; Appendix Table A-3). A sufficient number of tagged fish were captured in 1996 ( $\mathrm{mn}>30$ ) to calculate 95\% confidence intervals for exploitation estimates (all fisheries combined) downstream from Bonneville Dam and systemwide.

Mean fork length of northern squawfish harvested systemwide in 1996 was $355 \mathrm{~mm}$ in the sport-reward fishery, $391 \mathrm{~mm}$ in the dam-angling fishery, and $408 \mathrm{~mm}$ in the site-specific fishery (Figure 2). Mean fork length increased from 1995 in the sport-reward (8.6\%) and dam-angling $(6.5 \%)$ fisheries, and decreased slightly $(0.7 \%)$ in the site-specific fishery.

Mean sizes of northern squawfish harvested in specific areas by the sport-reward fishery in 1996 were within the range for other years, except fish harvested downstream from Bonneville Dam and in Lower Granite Reservoir were larger than in any other year (Table 1). Mean fork length of northern squawfish harvested by the dam-angling fishery in 1996 was higher than 1995 in Bonneville Dam tailrace and John Day Reservoir, and lower than any other year in Bonneville Reservoir. Sample size of northern squawfish harvested by the dam-angling fishery in The Dalles Reservoir was inadequate to estimate mean fork length. Mean fork length of northern squawfish harvested by the gill-net fishery in 1996 was higher than 1995 downstream from Bonneville Dam and in John Day Reservoir, lower in Bonneville and McNary reservoirs, and similar to 1995 in the Dalles Reservoir, Sample sizes were small $(<200)$ for all locations except Bonneville Reservoir.

In 1996, the various fisheries reported 65,814 incidentally-caught fish including northern squawfish $<250 \mathrm{~mm}$ fork length (Table 2). The incidental catch rate was $27.0 \%$ in the sportreward fishery, $3.6 \%$ in the dam-angling fishery, and $54.6 \%$ in the gill-net fishery. Northern squawfish $<250 \mathrm{~mm}$, other cyprinids, smallmouth bass, catostomids, and white sturgeon were the most common incidentally-caught fish. Salmonids made up only $0.3 \%$ of the total catch and $1.2 \%$ of the incidental catch for all fisheries combined. The proportion of predator-sized $(\geq 250 \mathrm{~mm}$ fork length) northern squawfish relative to the total number of northern squawfish harvested was highest in the dam-angling fishery $(98.7 \%)$ and lowest in the sport-reward fishery $(87.1 \%)$.

Results from the "Loss Estimate Spreadsheet Model" indicate that potential predation by northern squawfish on juvenile salmonids in 1997 may range from $45 \%$ to $75 \%$ of pre-program levels, with a median estimate of $62 \%$ (Figure 3). Continued exploitation at mean 1991-96 levels will not result in further reductions in predation; predation will remain similar to 1997 levels unless exploitation is increased. 


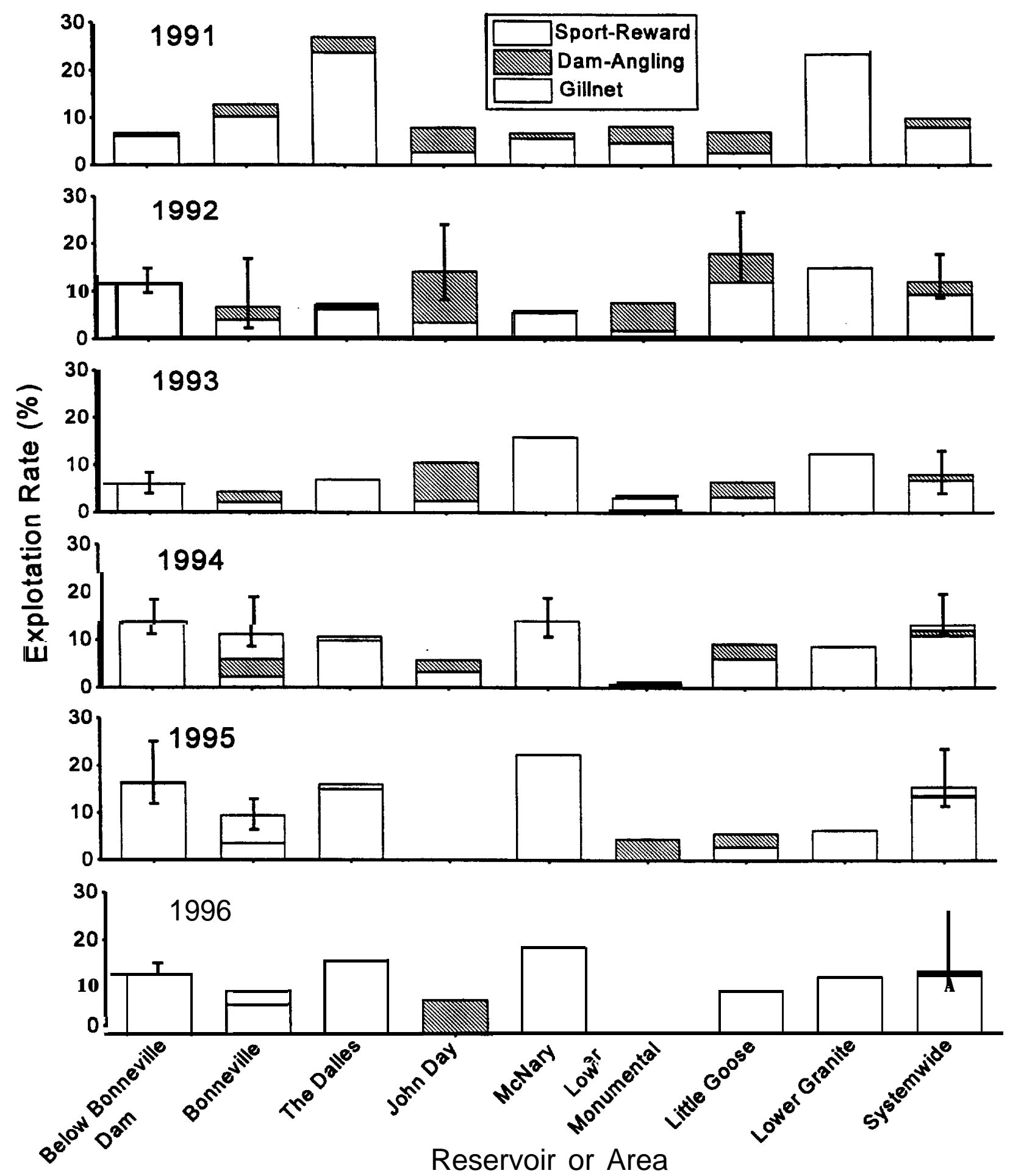

Figure 1. Exploitation of northern squawfish $\geq 250 \mathrm{~mm}$ fork length by fishery and area, 1991-96. Confidence intervals for all fisheries combined (96\%; vertical bars) are included where a sufficient number of tagged northern squawfish were recaptured to estimate upper and lower bounds. 
Table 1. Mean fork length (mm) of northern squawfish harvested from 1990-96 in the lower Columbia and Snake rivers by the sport-reward, dam-angling, and site-specific gill-net fisheries.

Mean fork length (mm)

Fishery: Location

Dam Angling:

Bonneville Dam Tailrace

Bonneville Reservoir

The Dalles Reservoir

John Day Reservoir

McNary Reservoir

Ice Harbor Reservoir

Lower Monumental Reservoir

Little Goose Reservoir

Lower Granite Reservoir

Sport Reward:

Downstream from Bonneville Dam

Bonneville Reservoir

The Dalles Reservoir

John Day Reservoir

McNary Reservoir

Ice Harbor Reservoir

Lower Monumental Reservoir

Little Goose Reservoir

Lower Granite Reservoir

Gill Net:

Downstream from Bonneville Dam

Bonneville Reservoir

The Dalles Reservoir

John Day Reservoir

McNary Reservoir

Ice Harbor Reservoir

Lower Monumental Reservoir

Little Goose Reservoir

Lower Granite Reservoir $\begin{array}{lllllll}1990 & 1991 & 1992 & 1993 & 1994 & 1995 & 1996\end{array}$

$\begin{array}{lrrrrrr}414 & 417 & 388 & 390 & 376 & 365 & 370 \\ 407 & 417 & 416 & 415 & 413 & 366 & 363 \\ 421 & 404 & 380 & 420 & 390 & 343 & -- \\ 416 & 414 & 417 & 416 & 437 & 389 & 418 \\ 393 & 393 & 375 & 408 & -- & -- & -- \\ -- & 375 & 369 & 414 & -- & -- & -- \\ -- & 325 & 309 & 341 & -- & -- & -- \\ -- & 380 & 346 & 373 & 370 & -- & -- \\ -- & -- & -- & 377 & -- & -- & --\end{array}$

$\begin{array}{lllllrr}-- & 332 & 337 & 316 & 337 & 325 & 345 \\ -- & 343 & 347 & 312 & 323 & 305 & 344 \\ -- & 344 & 369 & 369 & 358 & 359 & 349 \\ 377 & 370 & 367 & 370 & 329 & -- & -- \\ -- & 354 & 356 & 358 & 366 & 323 & 359 \\ -- & 357 & 360 & 317 & 407 & -- & -- \\ -- & 338 & 330 & 307 & 428 & -- & -- \\ -- & 312 & 347 & 344 & 376 & -- & -- \\ -- & 343 & 345 & 362 & 348 & 322 & 375\end{array}$

$\begin{array}{rrrrrrr}-- & -- & -- & -- & -- & 374 & 391 \\ -- & -- & -- & 371 & 411 & 416 & 409 \\ -- & -- & -- & -- & 395 & 396 & 397 \\ -- & -- & -- & -- & 366 & 370 & 403 \\ -- & -- & -- & -- & 387 & 363 & 353 \\ -- & -- & -- & -- & -- & 386 & -- \\ -- & -- & -- & -- & -- & 345 & -- \\ -- & -- & -- & -- & -- & 379 & -- \\ -- & -- & -- & -- & 377 & 370 & --\end{array}$ 

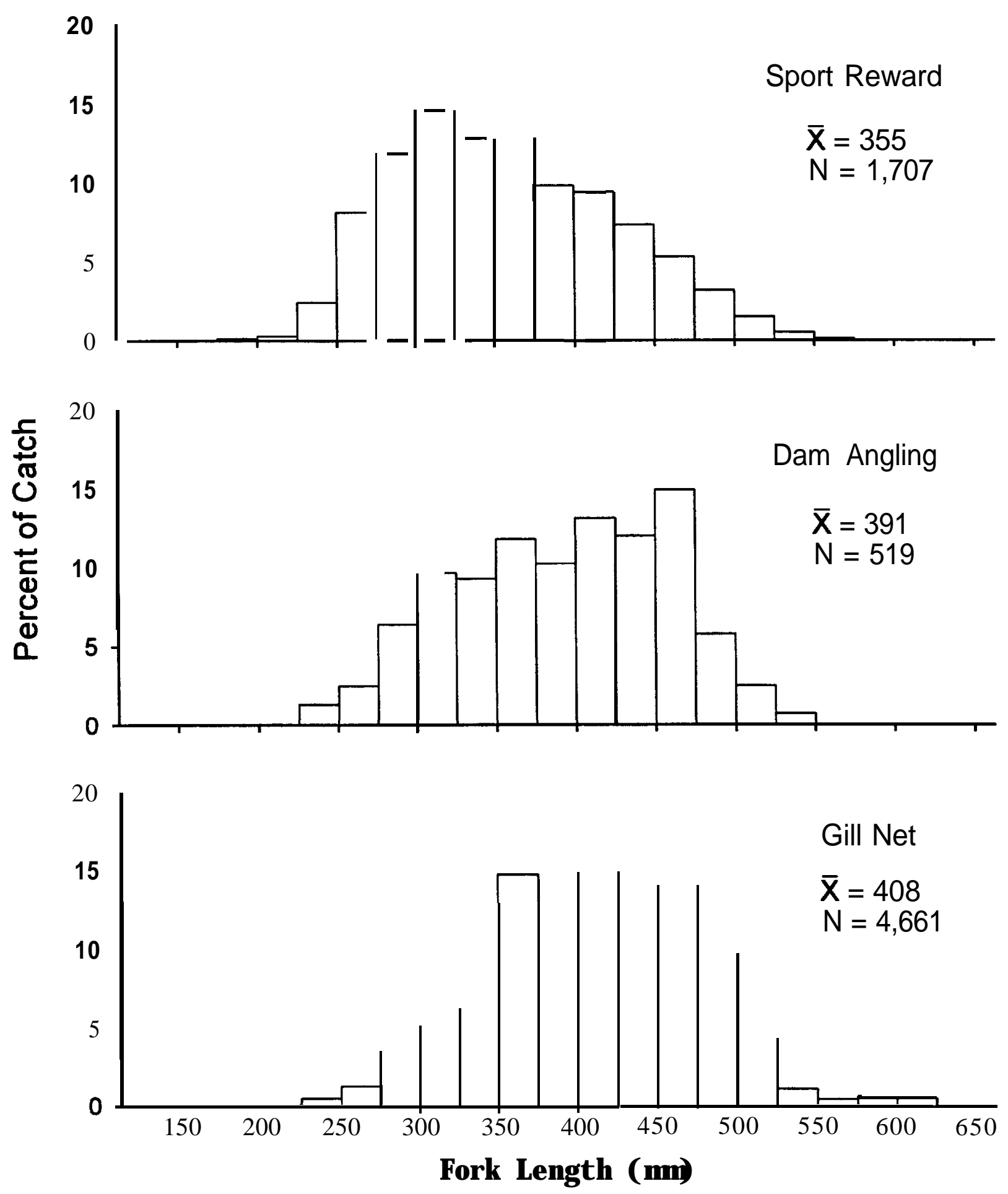

Figure 2. Size composition and mean fork length of northern squawfish from subsamples of fish harvested systemwide by sport-reward, dam-angling, and site-specific gill-net fisheries during 1996. $\mathrm{N}=$ subsample size. 


\section{Biological Evaluation}

Density indices for northern squawfish in 1996 were generally similar to those of 1995 (Appendix Table B-l). Total (all sampling areas combined) density increased slightly downstream from Bonneville Dam, in John Day Reservoir, and in the upper portion of Lower Granite Reservoir, and decreased in Bonneville, The Dalles, Lower Monumental, and Little Goose Reservoirs. Density indices for seven of the 19 areas sampled were the lowest recorded since biological evaluation began in 1990.

Relative abundance of northern squawfish declined slightly in Bonneville Reservoir, and in the tailrace zones of Lower Monumental and Little Goose reservoirs in 1996 relative to previous years (Figure 4; Appendix Table B-2). Abundance in the remaining areas were similar to or slightly higher than abundance in 1994-95. Mean abundance in Bonneville Dam tailrace, and Bonneville, The Dalles, and John Day reservoirs (areas sampled at least five years) was 48-60\% lower from 1994-96 than 1990-93.

Consumption in spring was lower in 1996 relative to previous years in all locations (Appendix Table B-3). Consumption in summer was also lower than previous years except in the boat restricted zones of Bonneville Dam tailrace and The Dalles Reservoir tailrace (Appendix Table B-4). We found no juvenile salmonids in the digestive tracts of nor-them squawfish collected at seven of 14 summer sampling sites, which resulted in consumption indices of zero for these sites. Among areas sampled at least five years, mean consumption from 1994-96 was $21-$ $41 \%$ lower in spring and 13-64\% lower in summer than 1990-93.

Predation indices in spring 1996 were lower than all prior years in every location (Figure 5; Appendix Table B-5). Predation in summer 1996 was higher than predation in 1994-95 in most tailrace and forebay areas, but was generally lower than predation prior to 1994 (Figure 6;

Appendix Table B-6). The mean decline in predation from pre- to post-1994 levels ranged from 40\% downstream from Bonneville Dam to $86 \%$ in Little Goose Dam tailrace. The mean decline in all areas was $69 \%$. Timing of consumption/predation sampling coincided with peaks in downstream passage ofjuvenile salmonids in all sampling areas during spring, and at John Day Dam (forebay and tailrace), McNary Dam (tailrace), and McNary Reservoir (mid-reservoir) during summer (Appendix C). 


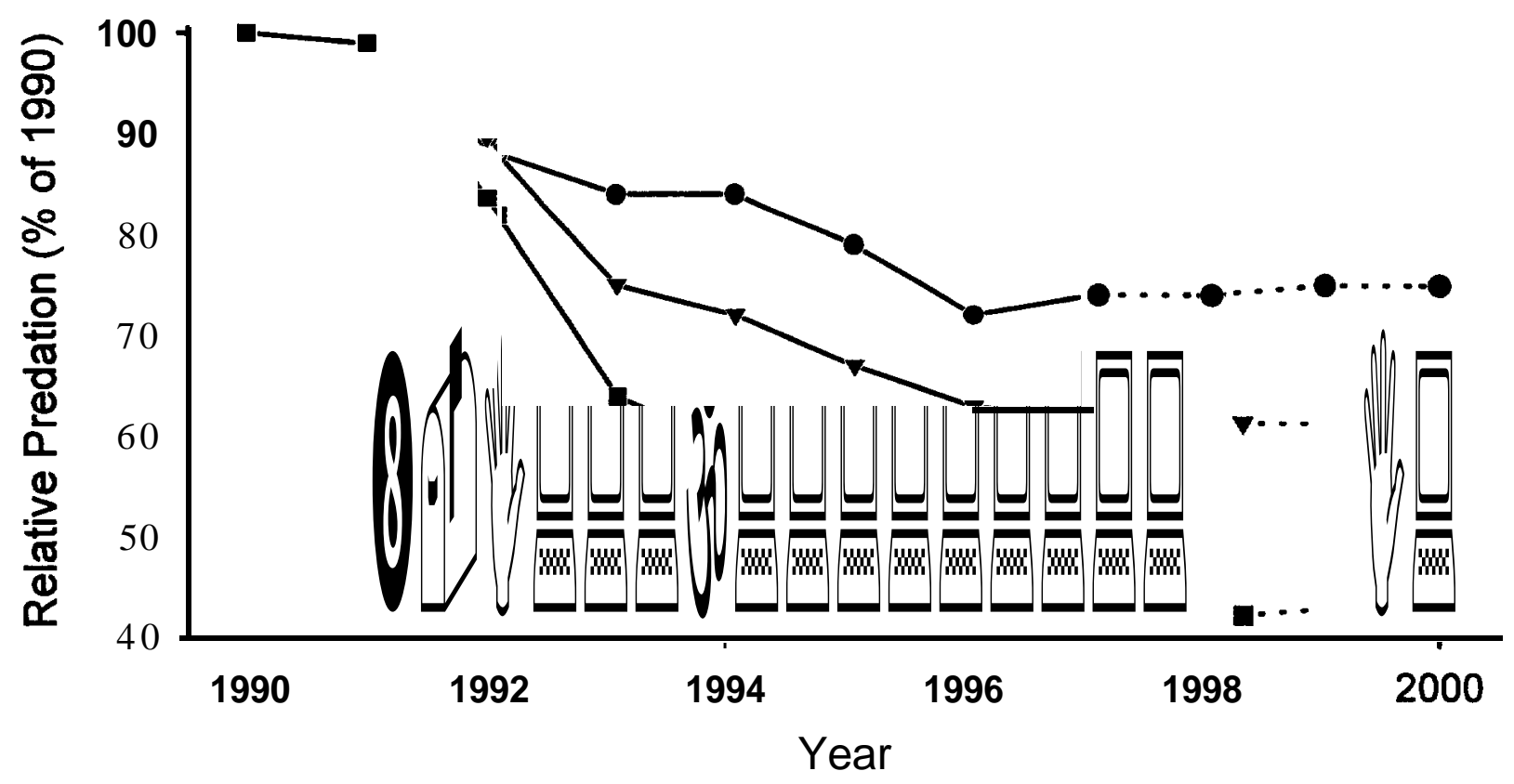

Figure 3. Maximum (circles), median (triangles), and minimum (squares) estimates of potential predation on juvenile salmonids by northern squawfish relative to predation prior to implementation of the northern squawfish management program. Dashed lines indicate predation in future years if exploitation is maintained at mean 1991-96 levels. 


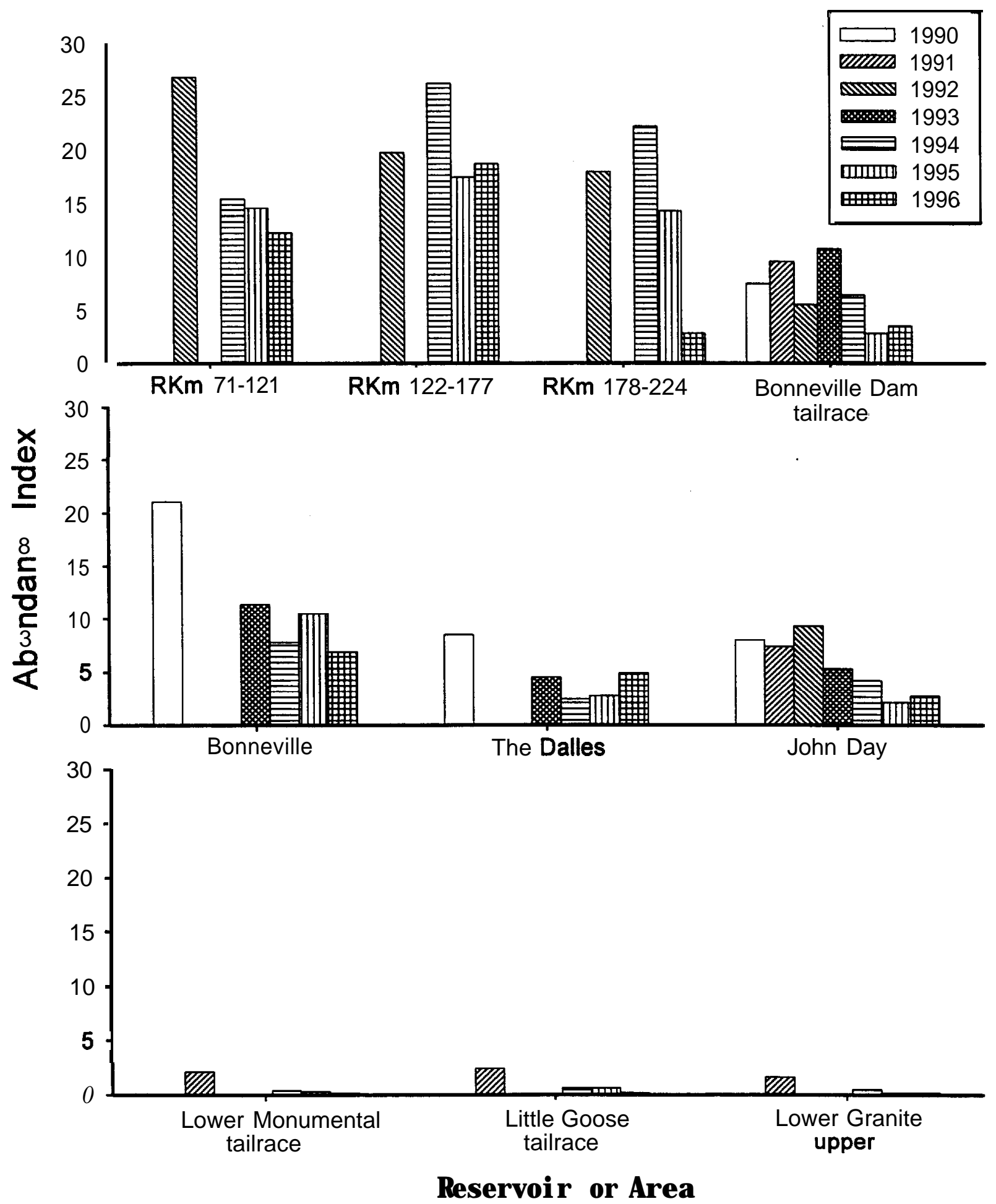

Figure 4. Index of northern squawfish abundance from 1990-96 for sampling locations in the lower Columbia and Snake rivers. $\mathrm{RKm}=$ river kilometer. 


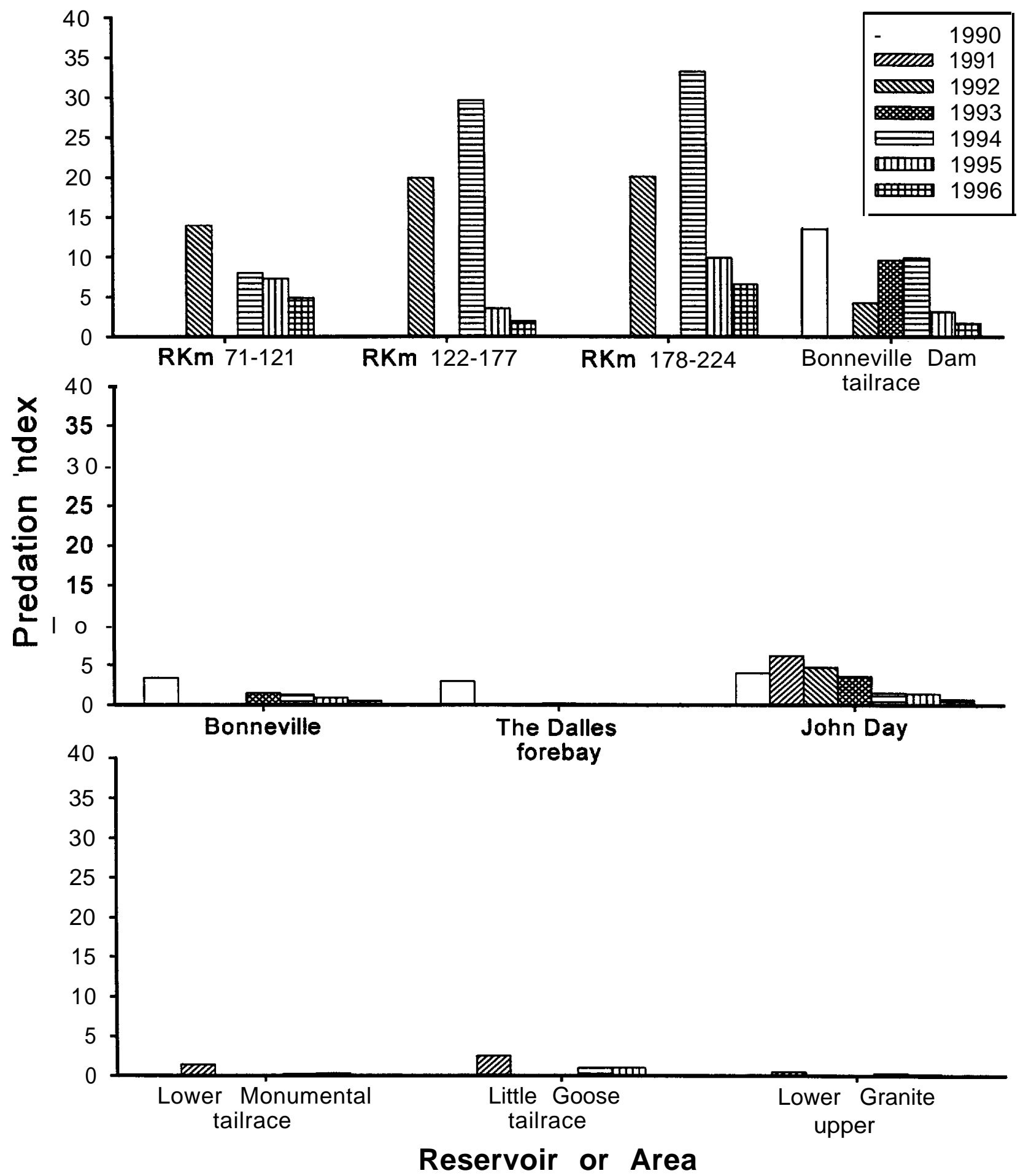

Figure 5. Index of predation by northern squawfish during spring from 1990-96 for sampling locations in the lower Columbia and Snake rivers. $\mathrm{RKm}=$ river kilometer. 


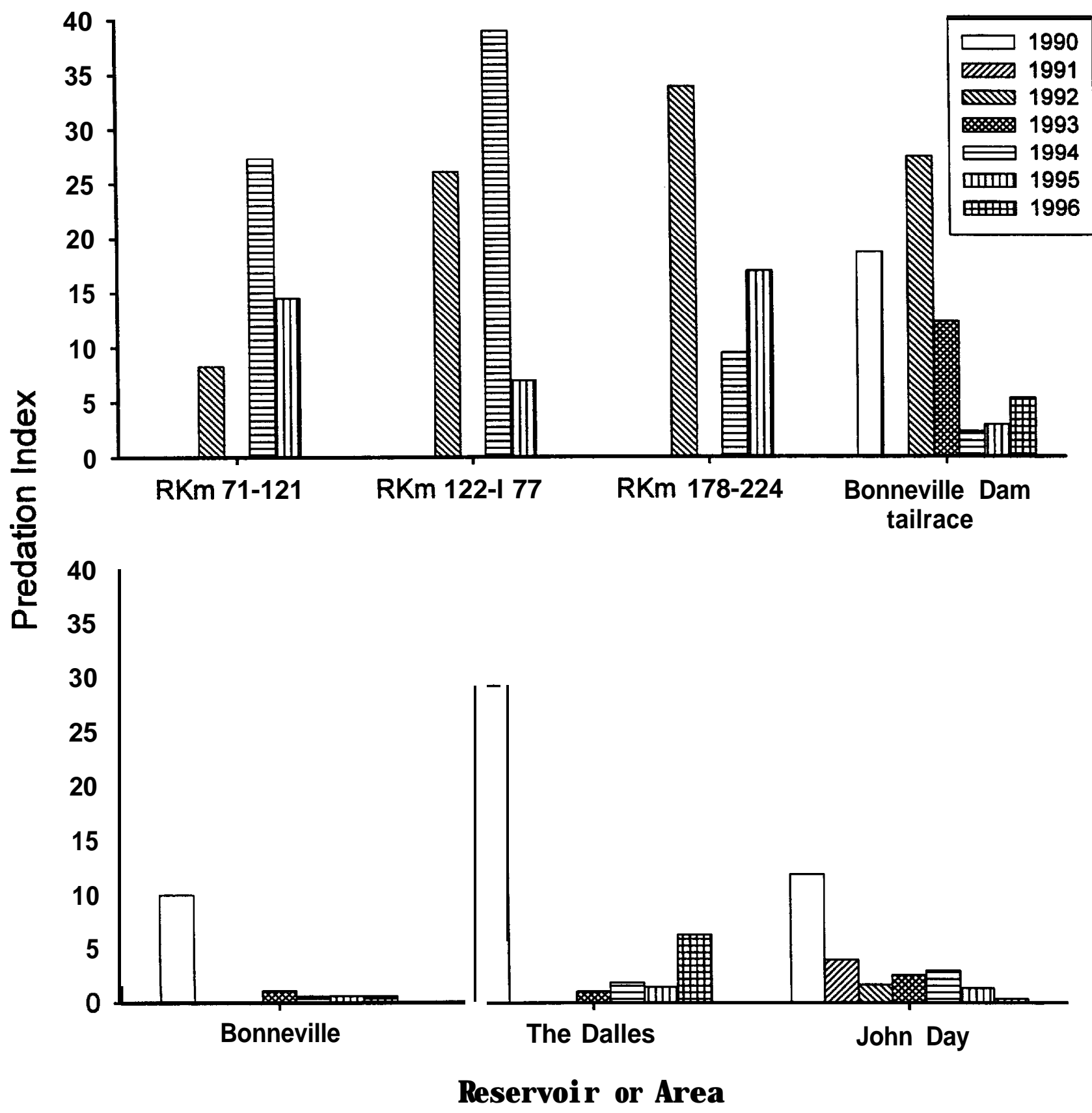

Figure 6. Index of predation by northern squawfish during summer from 1990-96 for sampling locations in the lower Columbia and Snake rivers. Predation indices for The Dalles Reservoir excludes the mid-reservoir. R.Km = river kilometer. 
Year-class strength of northern squawfish was highly variable; however, variations were generally similar among areas (Figure 7). Differences among areas were less than $25 \%$ except in 1987. Year classes were generally stronger from 1989-92 than in 1987 and 1988.

Proportional stock density of northern squawfish has generally decreased since implementation of the NSMP (Figure 8). Observed PSDs initially remained stable or increased, as a relatively strong 1985 year class was recruited from stock to quality size. Observed PSDs then generally decreased as relatively strong 1989-91 year classes were recruited to stock size. In Bonneville and John Day reservoirs, observed PSDs were lower than PSDs expected without implementation of the management program. After 1993, observed PSDs were very similar to PSDs expected with implementation of the NSMP. Observed PSDs followed expected trends downstream from Bonneville Dam except in 1995, when the observed PSD was higher than expected.

Estimates of mean fecundity and mean relative fecundity in each reservoir or reach increased from 1995 to 1996; however, fecundity in 1996 was generally similar to or less than fecundity from 199 1-94 (Table 3). Although regression parameters for fecundity-fork length relationships differed among years, there was no evidence that fecundity of northern squawfish increased from 199 1-96 (Table 4).

Regression parameters for length-age relationships differed among some years for female northern squawfish downstream from Bonneville Dam, and in Bonneville and John Day Reservoirs, but were similar among years in Lower Granite Reservoir (Table 5). There was no trend in increasing growth from 1990-96 in any area, despite differences in growth among a few years.

\section{DISCUSSION}

Rieman and Beamesderfer (1990) predicted that sustained exploitation of northern squawfish $>275 \mathrm{~mm}$ fork length at an annual rate of $10-20 \%$ would reduce losses of juvenile salmonids to predation by $50 \%$. Total systemwide exploitation by the three fisheries in 1996 was $12.9 \%$, the third consecutive year that exploitation has exceeded 10\%. Systemwide exploitation from 199 195 averaged $11.7 \%$ (Zimmerman et al. in press). As in previous years, sport-reward exploitation greatly exceeded exploitation by other fisheries. The dam-angling and site-specific gill-net fisheries, while contributing less to exploitation, harvested localized concentrations of northern squawfish which may have aggregated to feed on juvenile salmonids (Beamesderfer and Rieman 1991; Poe et al. 1991; Collis et al. 1995). These fisheries also harvested larger northern squawfish than the sport-reward fishery, and captured a much smaller number of other species.

If exploitation rates remain similar to mean 1991-96 levels, it is likely that no further reductions in potential predation will be realized. Predation will remain at approximately $62 \%$ of pre-program levels. Exploitation rates lower than mean 199 l-96 levels will result in increases in 


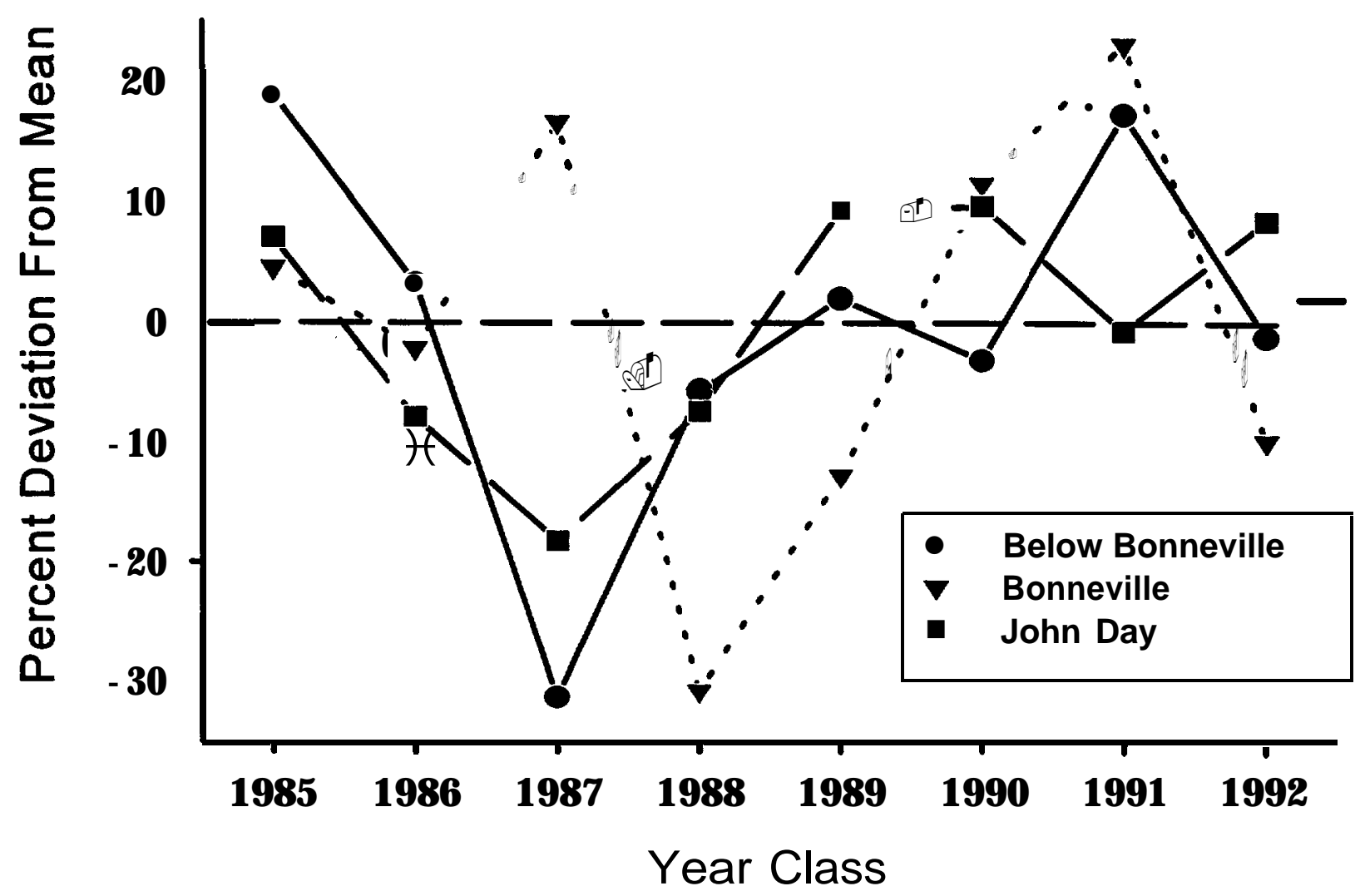

Figure 7. Index of relative year-class strength of northern squawfish in the Columbia River downstream from Bonneville Dam, in Bonneville Reservoir, and in John Day Reservoir. 

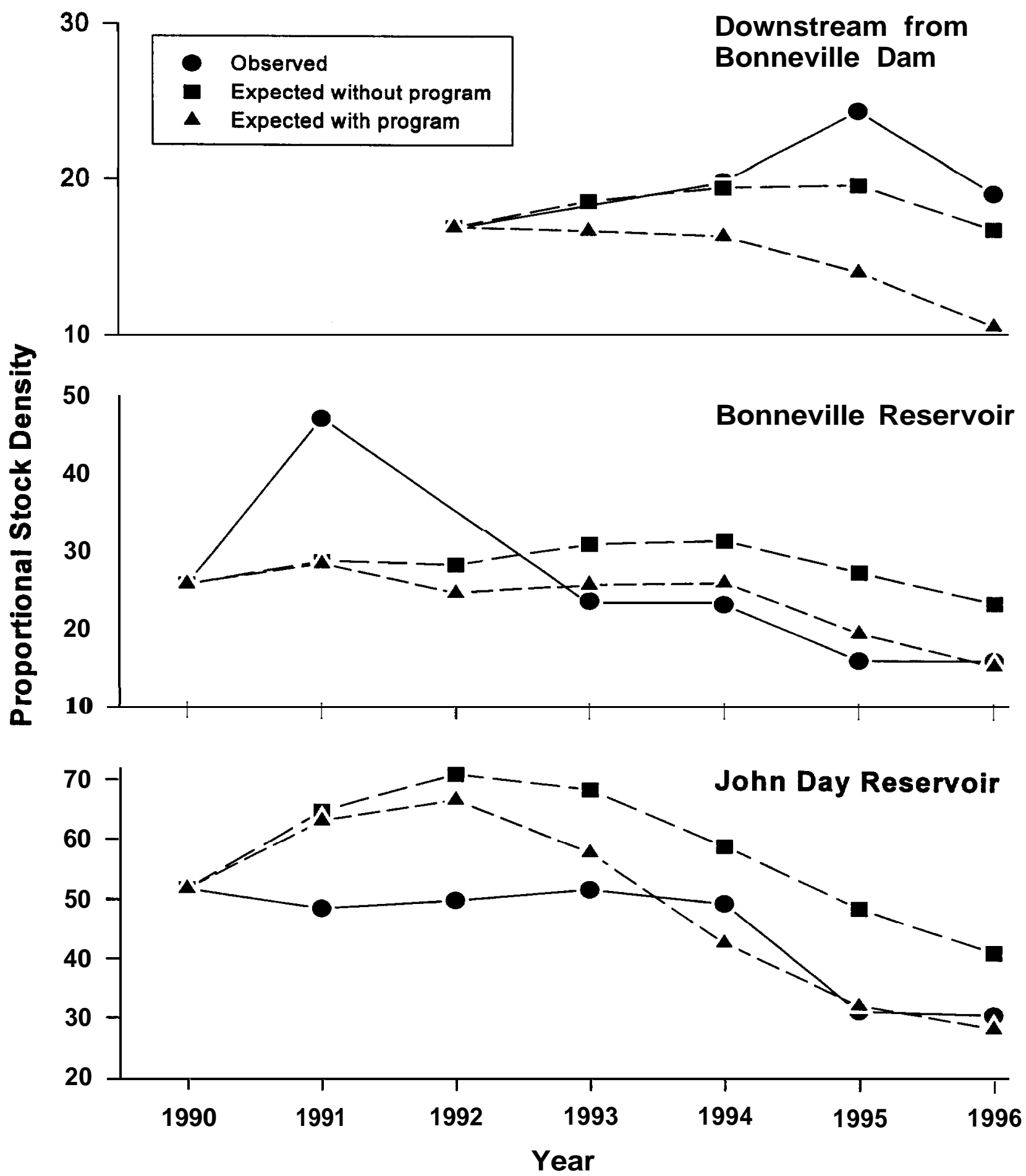

Figure 8. Observed and expected proportional stock density with and without implementation of the Northern Squawfish Management Program from 1990-96 in the Columbia River downstream from Bonneville Dam, in Bonneville Reservoir, and in John Day Reservoir. 
Table 3. Mean fecundity (number of developed eggs per female), mean relative fecundity (MRF; number of developed eggs per gram of body weight), and sample size (N) of northern squawfish in selected areas of the Columbia and Snake rivers, 1991-96.

Location, parameter

1991

1992

1993

1994

1995

1996

Downstream from

Bonneville Dam

Mean fecundity
MRF

$\mathrm{N}$

Bonneville Reservoir

Mean fecundity

MRF

$\mathrm{N}$

John Day Reservoir

Mean fecundity

MRF

$\mathrm{N}$

Lower Granite Reservoir
Mean fecundity
MRF
$\mathrm{N}$

$\begin{array}{rrrrrr}37,500 & 25,069 & 22,410 & 26,717 & 18,865 & 24,047 \\ 40.01 & 38.74 & 37.68 & 37.37 & 31.32 & 40.79 \\ 59 & 247 & 267 & 84 & 121 & 39\end{array}$

$\begin{array}{rrrrrr}31,225 & 33,640 & 30,444 & 29,313 & 18,550 & 26,413 \\ 45.17 & 35.96 & 32.15 & 32.43 & 22.27 & 33.90 \\ 37 & 105 & 101 & 100 & 6 & 47\end{array}$

$\begin{array}{rrrrrr}30,699 & 32,026 & 26,016 & 27,638 & 17,792 & 36,487 \\ 28.90 & 32.40 & 24.72 & 24.93 & 20.80 & 31.05 \\ 66 & 109 & 95 & 60 & 12 & 51\end{array}$

$\begin{array}{rrrrrr}23,251 & 24,851 & 32,472 & 21,926 & 23,991 & 25,795 \\ 30.29 & 27.51 & 27.79 & 34.28 & 21.80 & 29.23 \\ 44 & 30 & 17 & 5 & 5 & 65\end{array}$


Table 4. Differences among years in joint $95 \%$ family confidence regions for parameter pairs of the regression of fecundity on fork length $(\mathrm{mm})$ of northern squawfish. $*=$ significant difference between years; $\mathrm{ns}=$ no difference between years.

Statistical Significance

Parameters

Location,

Year

1991

1992

1993

1994

19951996

Slope Intercept

Downstream from

Bonneville Dam
1991
1992
1993
1994
1995
1996

$\begin{array}{ll}-- & \\ * & -- \\ * & \text { ns } \\ * & * \\ * & * \\ * & \text { ns }\end{array}$

$\begin{array}{cc} & \\ - & \\ * & -- \\ * & * \\ * & \mathrm{~ns}\end{array}$

$\begin{array}{rr}254.6 & -66,804 \\ 106.5 & -15,081 \\ 127.1 & -23,421 \\ 180.7 & -41,757 \\ 67.6 & -6,037 \\ 172.3 & -36,648\end{array}$

Bonneville Reservoir

1991

1992

1993

1994

1996

$\begin{array}{rr}-- & \\ \mathrm{ns} & - \\ * & \mathrm{n} \\ * & \\ \mathrm{~ns} & \mathrm{n}\end{array}$

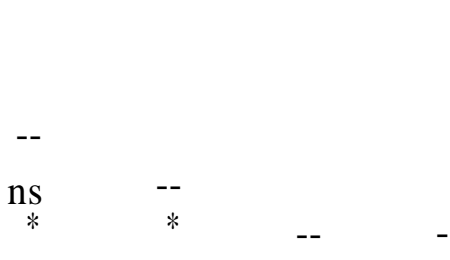

$229.7 \quad-58,353$

$145.5-26,444$

$105.4-13,113$

$98.5 \quad-11,666$

$172.0 \quad-40,410$

John Day Reservoir

1991

1992

1993

1994

1995

1996

$\begin{array}{cc}-- & \\ * & - \\ \mathrm{ns} & \\ \mathrm{ns} & \mathrm{n} \\ \mathrm{ns} & \\ * & \mathrm{n}\end{array}$

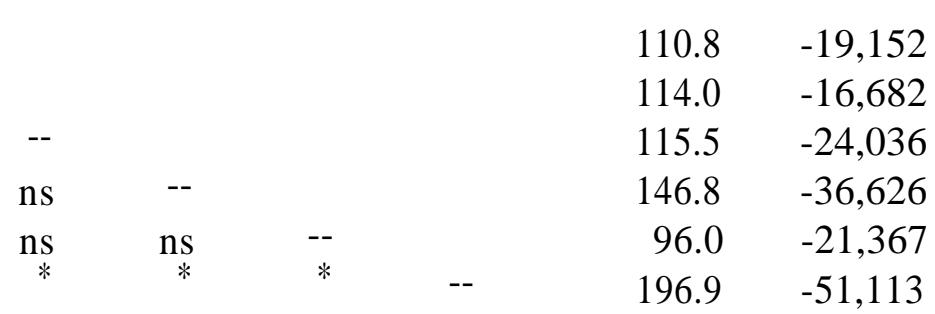

Lower Granite

Reservoir

1991

1992

1996

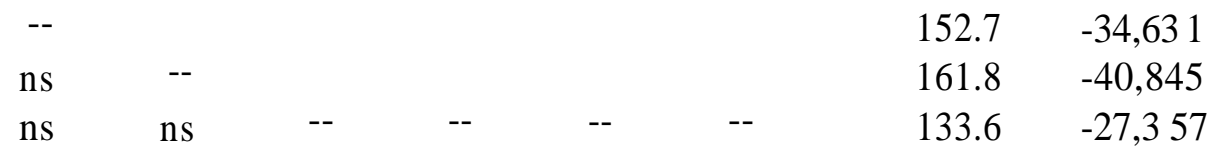


Table 5. Differences among years in joint $95 \%$ family confidence regions for parameter pairs of the regression of fork length $(\mathrm{mm})$ on age of female northern squawfish. $*=$ significant difference between years; $n s=$ no difference between years.

Statistical Significance

Parameters

Location,

$\begin{array}{llllllllll}\text { Year } & 1990 & 1991 & 1992 & 1993 & 1994 & 1995 & 1996 & \text { Slope } & \text { Intercept }\end{array}$

Downstream from

Bonneville Dam

1990
1991
1992
1993
1994
1995
1996

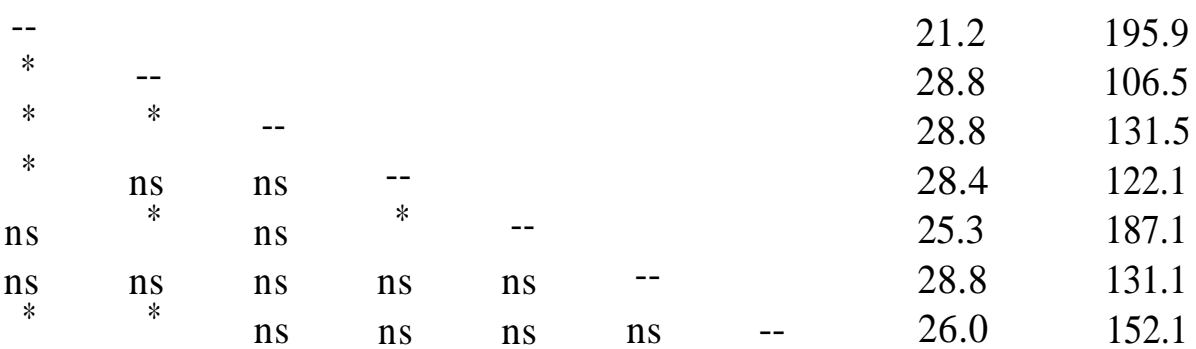

Bonneville Reservoir

1990

1993

1994

1995

1996

John Day Reservoir

1990

1991

1992

1993

1994

1995

1996

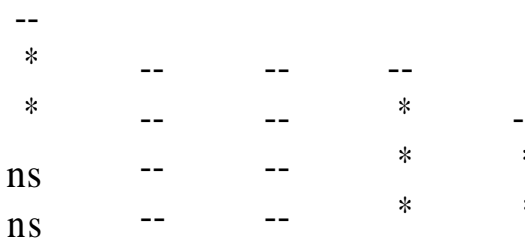

21.7

188.0

$28.8 \quad 127.4$

$27.6 \quad 168.9$

$24.0 \quad 183.2$

$22.6 \quad 192.2$

ns $\quad--\quad ~ 22.6$

$20.0 \quad 206.3$

$22.4 \quad 193.0$

$28.6 \quad 136.2$

$26.4 \quad 158.6$

$21.5 \quad 208.8$

$24.6 \quad 171.6$

$23.0 \quad 192.7$

Lower Granite

Reservoir

1991

$--\quad--$

1993

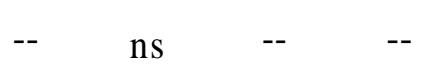

32.5

92.3

1995

$--\quad n s \quad--\quad n s$

29.6

108.7

1996

$--n$

$--\quad n s$

26.8

149.4

$31.3 \quad 124.7$

potential predation. Because exploitation from 1994-96 was higher than exploitation from 199 193, further reductions in predation may be feasible. These reductions will be small (1\% to $4 \%$ ) unless average exploitation is higher than 1994-96 levels. 
Reducing the number of large northern squawfish may improve salmonid survival if remaining northern squawfish do not consume salmonids at a higher rate (Beamesderfer et al. 1990).

Declining abundance and consumption of northern squawfish contributed to declines in predation on juvenile salmonids from 1990-96 in all areas. Our results indicate that northern squawfish are not consuming more juvenile salmonids in response to decreased abundance of northern squawfish. Density (and therefore abundance and predation) indices for the tailrace boatrestricted zones of The Dalles, Lower Monumental, and Little Goose reservoirs may be biased low because river conditions during 1996 limited our sampling of these areas.

Decreases in PSD were greater than could be explained by fluctuations in year-class strength, and indicate that sustained removals are changing the size structure of predator-sized northern squawfish. Observed and expected PSD values often differed in the early years of the NSMP, in part because estimates of expected PSD incorporate estimates of natural mortality and growth. Annual variations in mortality and growth are unpredictable; we therefore used estimates of natural mortality developed prior to sustained removals, and pooled 1990-96 growth data to estimate age-specific lengths. These data should be representative of long-term averages, but will not reflect annual variation around those averages. Differences between observed and expected PSD values have become smaller over a period of years, as annual variations in mortality and growth "average out."

If northern squawfish compensate for sustained exploitation with increased growth or fecundity rates, relative benefits of the NSMP will be diminished (Beamesderfer et al. 1996). While our estimates of fecundity and growth of female northern squawfish differed in some years, there was no evidence that northern squawfish are compensating for decreased abundance by increasing consumption and consequently growing faster, or by increasing fecundity. 


\section{REFERENCES}

Anderson, R.O. 1980. Proportional stock density (PSD) and relative weight (Wr): interpretive indices for fish populations and communities. Pages 27-33 in S. Gloss and B. Shupp, editors. Practical fisheries management: more with less in the 1980s. New York Chapter American Fisheries Society, Bethesda, MD.

Bagenal, T.B. 1968. Fecundity. Pages 160-169 in W.E. Ricker, editor. Methods for assessment of fish production in freshwater. International Biological Programme Handbook 3, Blackwell Scientific Publications, Oxford, England.

Beamesderfer, R.C., B.E. Rieman, J.C. Elliott, A.A. Nigro, and D.L. Ward. 1987. Distribution, abundance, and population dynamics of northern squawfish, walleye, smallmouth bass, and channel catfish in John Day Reservoir, 1986. Oregon Department of Fish and Wildlife, Contract number DE-AI79-82BP3 5097. 1986 Annual Report to Bonneville Power Administration, Portland, Oregon.

Beamesderfer, R.C., and B.E. Rieman. 1988. Size selectivity and bias in estimates of population statistics of smallmouth bass, walleye, and northern squawfish in a Columbia River reservoir. North American Journal of Fisheries Management 8: 505-5 10.

Bearnesderfer, R.C., B.E. Rieman, L.J. Bledsoe, and S. Vigg. 1990. Management implications of a model of predation by a resident fish on juvenile salmonids migrating through a Columbia River reservoir. North American Journal of Fisheries Management 10:290-304.

Beamesderfer, R.C., and B.E. Rieman. 1991. Abundance and distribution of northern squawfish, walleyes, and smallmouth bass in John Day Reservoir, Columbia River. Transactions of the American Fisheries Society 120:439-447.

Beamesderfer, R.C., D.L. Ward, and A.A. Nigro. 1996. Evaluation of the biological basis for a predator control program on northern squawfish (Ptychocheihs oregonensis) in the Columbia and Snake rivers. Canadian Journal of Fisheries and Aquatic Sciences 53 :28982908.

Collis, K., R.E. Beaty, and B.R. Crain. 1995. Changes in catch rate and diet of northern squawfish associated with the release of hatchery-reared juvenile salmonids in a Columbia River reservoir. North American Journal of Fisheries Management 15:346-3 57.

Elliott, J. M. 1977. Some methods for the statistical analysis of samples of benthic invertebrates, 2nd edition. Freshwater Biological Association Scientific Publication 25.

Knutsen, C.J., D.L. Ward, T.A. Friesen, and M.P. Zimmerman. 1995. Development of a systemwide predator control program: Indexing and fisheries evaluation. Oregon Department of Fish and Wildlife, Contract number DE-AI79-90BP07084 1994 Annual Report to the Bonneville Power Administration, Portland, Oregon. 
Mesa, M.G., S.D. Duke, and D.L. Ward. 1990. Spatial and temporal variation in proportional stock density and relative weight of smallmouth bass in a reservoir. Journal of Freshwater Ecology 5:323-339.

Neter, J., W. Wasserman, and M.H. Kutner. 1985. Applied linear statistical models, 2nd edition. Irwin Press, Homewood, Illinois.

Parker, R.M., M.P. Zimmerman, and D.L. Ward. 1994. Development of a system-wide predator control program: Indexing and fisheries evaluation. Oregon Department of Fish and Wildlife, Contract number DE-AI79-90BP07096 1992 Annual Report to the Bonneville Power Administration, Portland, Oregon.

Parker, R.M., M.P. Zimmerman, and D.L. Ward. 1995. Variability in biological characteristics of northern squawfish in the lower Columbia and Snake rivers. Transactions of the American Fisheries Society 124:335-346.

Poe, T.P., H.C. Hansel, S. Vigg, D.E. Palmer, and L.A. Prendergast. 1991. Feeding of predaceous fishes on out-migrating juvenile salmonids in the John Day Reservoir, Columbia River. Transactions of the American Fisheries Society 120:405-420.

Ricker, W.E. 1975. Computation and interpretation of biological statistics of fish populations. Fisheries Research Board of Canada Bulletin 191.

Rieman, B.E., and R.C. Beamesderfer. 1990. Dynamics of a northern squawfish population and the potential to reduce predation on juvenile salmonids in a Columbia River reservoir. North American Journal of Fisheries Management 10:228-241.

Vigg, S., C.C. Burley, D.L. Ward, C. Mallette, S. Smith, and M. Zimmerman. 1990.

Development of a system-wide predator control program: Stepwise implementation of a predation index, predator control fisheries, and evaluation plan in the Columbia River basin. Oregon Department of Fish and Wildlife, Contract number DE-BI79-90BP07084. 1990 Annual Report to the Bonneville Power Administration, Portland, Oregon.

Ward, D.L., M.P. Zimmerman, R.M. Parker, and S.S. Smith. 1993. Development of a systemwide predator control program: Indexing, fisheries evaluation, and harvesting technology development. Oregon Department of Fish and Wildlife, Contract number DE-BI7990BP07084. 1991 Annual Report to the Bonneville Power Administration, Portland, Oregon.

Ward, D.L., J.H. Petersen, and J.J. Loch. 1995. Index of predation on juvenile salmonids by northern squawfish in the lower and middle Columbia River and in the lower Snake River. Transactions of the American Fisheries Society 124:321-334.

Zimmerman, M.P., C. Knutsen, D.L. Ward, and K. Anderson. 1995. Development of a systemwide predator control program: Indexing and fisheries evaluation. Oregon Department of Fish and Wildlife, Contract number DE-AI79-90BP07084 1993 Annual Report to the Bonneville Power Administration, Portland, Oregon. 
Zimmerman, M.P., D.L. Ward, T.A. Friesen, and C.J. Knutsen. In press. Development of a system-wide predator control program: Indexing and fisheries evaluation. Oregon Department of Fish and Wildlife, Contract number DE-AI79-90BP07084 1995 Annual Report to the Bonneville Power Administration, Portland, Oregon. 


\section{APPENDIX A}

Exploitation of Northern Squawfish by Reservoir and Fishery, 199 1-96 
Appendix Table A-l. Exploitation rates (\%) of northern squawfish2 $250 \mathrm{~mm}$ fork length for the sport-reward fishery, 199 1-96.

Area or

Reservoir

1991

1992

1993

1994

1995

1996

Downstream from

Bonneville Dam

Bonneville

7.6

11.4

10.9

4.0

23.6

6.2

2.8

3.4

5.3

McNary

Ice Harbor

1.0

Lower Monumental

4.5

Little Goose

2.4

Lower Granite

20.0

5.6

$-{ }^{b}$

1.8

11.9

15.0

6.0
2.1
7.0
2.4
15.9
$--{ }^{\mathrm{b}}$
3.1
3.3
12.5

13.6

16.1

12.7

2.2

9.8

3.2

14.0

14.9

6.1

2.4

0.0 "

15.5

Systemwide

8.5

9.3

6.8

$--b$

22.4

18.2

0.8

$-\mathrm{b}$

$--^{b}$

6.1

8.7

$0.0^{\mathrm{a}}$

$0.0^{\mathrm{a}}$

2.9

8.9

6.4

11.7

a Northern squawfish harvested, but no tags recovered.

b No northern squawfish tagged.

Appendix Table A-2. Exploitation rates (\%) of northern squawfish> $250 \mathrm{~mm}$ fork length for the dam-angling fishery, 199 1-96.

Area or

Reservoir

1991

1992

1993

1994

1995

1996

Downstream from

Bonneville Dam

Bonneville

0.9
2.7

2.7
3.3

0.2

2.8

1.0

0.0 "

2.2

0.1

3.7

The Dalles

5.2

10.8

McNary

Ice Harbor

1.1

3.4

$0.0 "$

-. b

3.1

5.9

0.0 "

0.0 "

8.1

0.1

-. b

2.6

0.0 "

13.4

12.1

Lower Monumental

4.2

Lower Granite

$<0.1$

6.0

$0.0^{\mathrm{a}}$

$0.0 "$

3.3

0.0 "

$0.0 "$

3.1

0.0 "

0.2

0.0 "

0.0 "

$0.0 "$

$0.0 "$

$-\mathrm{b}$

4.5

2.8

$0.0 "$

0.0 "

$0.0 "$

2.2

2.7

1.3

1.1

0.3

0.3

a Northern squawfish harvested, but no tags recovered.

b No northern squawfish tagged. 
Appendix Table A-3. Exploitation rates (\%) of northern squawfish> $250 \mathrm{~mm}$ fork length for the site-specific gill-net fishery, 1994-96.

$\begin{array}{lccc}\text { Area or } & & & \\ \text { Reservoir } & 1994 & 1995 & 1996 \\ & \mathbf{a} & 0.2 & 0.0^{\mathbf{b}} \\ \text { Downstream from Bonneville Dam } & 5.3 & 5.9 & 3.0 \\ \text { Bonneville } & 0.9 & 1.1 & 0.0^{\mathbf{b}} \\ \text { The Dalles } & 0.0^{\mathbf{b}} & 0.0^{\mathbf{b}} & 0.0^{\mathbf{b}} \\ \text { John Day } & 0.0^{\mathbf{b}} & 0.0^{\mathbf{b}} & 0.0^{\mathbf{b}} \\ \text { McNary } & ---^{\mathbf{a c}} & -\mathbf{a}^{\mathbf{c}} & -^{\mathbf{a}} \\ \text { Ice Harbor } & 0.0^{\mathbf{b}} & 0.0^{\mathbf{b}} & -^{\mathbf{a}} \\ \text { Lower Monumental } & --^{\mathbf{a}} & 0.0^{\mathbf{b}} & -^{\mathbf{a}} \\ \text { Little Goose } & 0.0^{\mathbf{b}} & 0.0^{\mathbf{b}} & 0.5 \\ \text { Lower Granite } & & & \\ \text { Systemwide } & 1.2 & 1.9 & \\ \text { a No fishing effort. } & & & \\ \text { b Northern squawfish harvested, but no tags recovered. } & & \\ { }^{\mathbf{c}} \text { No northern squawfish tagged. } & & \end{array}$

Appendix Table A-4. Total exploitation rates of northern squawfish2 $250 \mathrm{~mm}$ fork length, 199 196.

Area or reservoir

1991

1992

1993

1994

1995

1996

Downstream from

Bonneville Dam

8.6

11.7

6.0

13.8

16.5

12.7

Bonneville

13.6

6.8

4.3

11.2

9.4

9.1

The Dalles

26.9

7.2

7.0

10.7

16.0

15.5

John Day

8.0

14.2

10.5

0.0

7.0

McNary

6.5

5.6

16.0

5.8

22.4

18.2

Ice Harbor

4.4

$--^{a}$

14.0

$-{ }^{\mathrm{a}}$

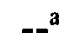

Lower Monumental

7.6

7.7

3.1

0.8

4.5

0.0

Little Goose

17.9

Lower Granite

20.0

15.0

6.6

9.2

5.7

8.9

12.5

8.7

6.4

11.7

Systemwide

10.7

12.0

8.1

13.2

15.5

12.9

a No northern squawfish tagged. 
Appendix Table A-5. Dates for each sampling period in 1996.

\begin{tabular}{clcl} 
Period & Dates & Period & \multicolumn{1}{c}{ Dates } \\
1 & Before April 1 & 15 & July 1 - July 7 \\
2 & April 1 - April 7 & 16 & July 8 - July 14 \\
3 & April 8 - April 14 & 17 & July 15 - July 2 1 \\
4 & April 15 -April 21 & 18 & July 22 - July 28 \\
5 & April 22 - April 28 & 19 & July 29 - August 4 \\
6 & April 29 - May 5 & 20 & August 5 - August 11 \\
7 & May 6 - May 12 & 21 & August 12 - August 18 \\
8 & May 13 - May 19 & 22 & August 19 - August 25 \\
9 & May 20 - May 26 & 23 & August 26 - September 1 \\
10 & May 27 - June 2 & 24 & September 2 - September 8 \\
11 & June 3 - June 9 & 25 & September 9 - September 15 \\
12 & June 10 - June 16 & 26 & September 16 - September 22 \\
13 & June 17 - June 23 & 27 & September 23 - September 29 \\
14 & June 24 - June 30 & &
\end{tabular}


Appendix Table A-6. Exploitation of northern squawfish downstream from Bonneville Dam in 1996. $\mathrm{T}=$ number of fish tagged. $\mathrm{M}=$ number of tagged fish at large. Misc. $=$ tagged fish recaptured outside the program area or fisheries.

\begin{tabular}{|c|c|c|c|c|c|c|c|c|c|}
\hline \multirow{2}{*}{$\begin{array}{l}\text { Time } \\
\text { neriod }\end{array}$} & \multicolumn{5}{|c|}{ Recaptures } & \multirow[b]{2}{*}{ M } & \multicolumn{3}{|c|}{ Exploitation } \\
\hline & $\mathrm{T}$ & sport & Dam & Net & Misc. & & sport & Dam & Net \\
\hline 1 & & -- & -- & -- & -- & -- & -- & & \\
\hline 2 & 83 & -- & -- & -- & -- & - & -- & & \\
\hline 3 & 334 & -- & -- & - & -- & 83 & -- & -- & -- \\
\hline 4 & 358 & -- & -- & -- & -- & 417 & -- & -- & - \\
\hline 5 & -- & -- & -- & & & 775 & & - & -- \\
\hline 6 & -- & 3 & -- & -- & -- & 775 & 0.0039 & -- & -- \\
\hline 7 & -- & 2 & -- & -- & -- & 772 & 0.0026 & & \\
\hline 8 & & 4 & -- & -- & -- & 770 & 0.0052 & -- & -- \\
\hline 9 & & 2 & - & -- & -- & 766 & 0.0026 & -- & -- \\
\hline 10 & -- & 2 & -- & & & 764 & 0.0026 & -- & -- \\
\hline 11 & -- & 1 & -- & -- & -- & 762 & 0.0013 & -- & -- \\
\hline 12 & -- & 4 & -- & -- & -- & 761 & 0.0053 & & \\
\hline 13 & & 2 & -- & -- & 1 & 757 & 0.0026 & -- & -- \\
\hline 14 & -- & 9 & -- & -- & -- & 754 & 0.0119 & -- & -- \\
\hline 15 & -- & 11 & -- & & & 745 & 0.0148 & - & -- \\
\hline 16 & -- & 11 & -- & & & 734 & 0.0150 & -- & -- \\
\hline 17 & -- & 8 & -- & & & 723 & 0.0111 & -- & -- \\
\hline 18 & -- & 7 & -- & -- & -- & 715 & 0.0098 & -- & -- \\
\hline 19 & -- & 7 & -- & -- & 2 & 708 & 0.0099 & -- & -- \\
\hline 20 & -- & 3 & -- & & & 699 & 0.0043 & -- & -- \\
\hline 21 & -- & 3 & -- & & & 696 & 0.0043 & -- & -- \\
\hline 22 & -- & 1 & -- & -- & -- & 693 & 0.0014 & -- & -- \\
\hline 23 & -- & 1 & -- & -- & -- & 692 & 0.0014 & -- & -- \\
\hline 24 & -- & 3 & -- & -- & -- & 691 & 0.0043 & -- & -- \\
\hline 25 & -- & 2 & -- & -- & -- & 688 & 0.0029 & -- & -- \\
\hline 26 & & 1 & -- & -- & -- & 686 & 0.0015 & -- & -- \\
\hline 27 & & 2 & -- & & & 685 & 0.0029 & & \\
\hline Total & 775 & 89 & 0 & 0 & 3 & -- & 0.1216 & 0.0000 & 0.0000 \\
\hline Adjuste & $g$ & & & & & & 0.1268 & 0.0000 & 0.0000 \\
\hline
\end{tabular}


Appendix Table A-7. Exploitation of northern squawfish in Bonneville Reservoir in 1996. T= number of fish tagged. $\mathrm{M}=$ number of tagged fish at large. Misc. = tagged fish recaptured outside the program area or fisheries.

\begin{tabular}{|c|c|c|c|c|c|c|c|c|c|}
\hline \multirow{2}{*}{$\begin{array}{l}\text { Time } \\
\text { Period } \\
\end{array}$} & \multicolumn{5}{|c|}{ Recaptures } & \multirow[b]{2}{*}{ M } & \multicolumn{3}{|c|}{ Exploitation } \\
\hline & $\mathrm{T}$ & Sport & D a m & Net & Misc. & & S port & $\mathrm{D}$ a m & Net \\
\hline 1 & 28 & -- & -- & -- & - & - & - & -- & -- \\
\hline 2 & 187 & -- & -- & -- & -- & 28 & - & -- & -- \\
\hline 3 & -- & -- & -- & -- & - & 215 & - & -- & -- \\
\hline 4 & -- & -- & -- & -- & - & 215 & -- & -- & -- \\
\hline 5 & -- & -- & - & 2 & - & 215 & - & - & 0.0093 \\
\hline 6 & -- & 1 & -- & 1 & -- & 213 & 0.0047 & -- & 0.0047 \\
\hline 7 & -- & -- & -- & -- & -- & 211 & & -- & -- \\
\hline 8 & -- & 1 & -- & -- & -- & 211 & 0.0047 & -- & -- \\
\hline 9 & -- & -- & -- & -- & -- & 210 & -- & -- & -- \\
\hline 10 & -- & 1 & -- & -- & -- & 210 & 0.0048 & -- & -- \\
\hline 11 & -- & 1 & -- & 1 & -- & 209 & 0.0048 & -- & 0.0048 \\
\hline 12 & -- & -- & -- & 2 & 1 & 207 & -- & - & 0.0097 \\
\hline 13 & -- & 2 & -- & -- & -- & 204 & 0.0098 & -- & -- \\
\hline 14 & -- & 1 & -- & -- & -- & 202 & 0.0050 & -- & -- \\
\hline 15 & -- & -- & -- & -- & -- & 201 & -- & -- & -- \\
\hline 16 & -- & 3 & -- & -- & -- & 201 & 0.0149 & -- & -- \\
\hline 17 & -- & -- & -- & -- & 2 & 198 & -- & -- & -- \\
\hline 18 & -- & -- & -- & -- & -- & 196 & -- & -- & -- \\
\hline 19 & -- & -- & -- & -- & -- & 196 & -- & -- & -- \\
\hline 20 & -- & -- & -- & -- & -- & 196 & - & -- & -- \\
\hline 21 & -- & -- & -- & -- & 1 & 196 & -- & -- & -- \\
\hline 22 & -- & 2 & -- & -- & -- & 195 & 0.0103 & -- & -- \\
\hline 23 & -- & -- & -- & -- & -- & 193 & -- & -- & -- \\
\hline 24 & -- & -- & -- & -- & -- & 193 & -- & -- & -- \\
\hline 25 & -- & -- & -- & -- & -- & 193 & -- & -- & -- \\
\hline 26 & -- & -- & -- & -- & -- & 193 & -- & - & -- \\
\hline 27 & -- & -- & -- & -- & -- & 193 & -- & -- & -- \\
\hline Total & 215 & 12 & 0 & 6 & 4 & -- & 0.0589 & 0.0000 & 0.0284 \\
\hline Adjuste & r tag & & & & & 0.0614 & 0.0 & 00000. & 0296 \\
\hline
\end{tabular}


Appendix Table A-S. Exploitation of northern squawfish in The Dalles Reservoir in 1996. $\mathrm{T}=$ number of fish tagged. $\mathrm{M}=$ number of tagged fish at large. Misc. $=$ tagged fish recaptured outside the program area or fisheries.

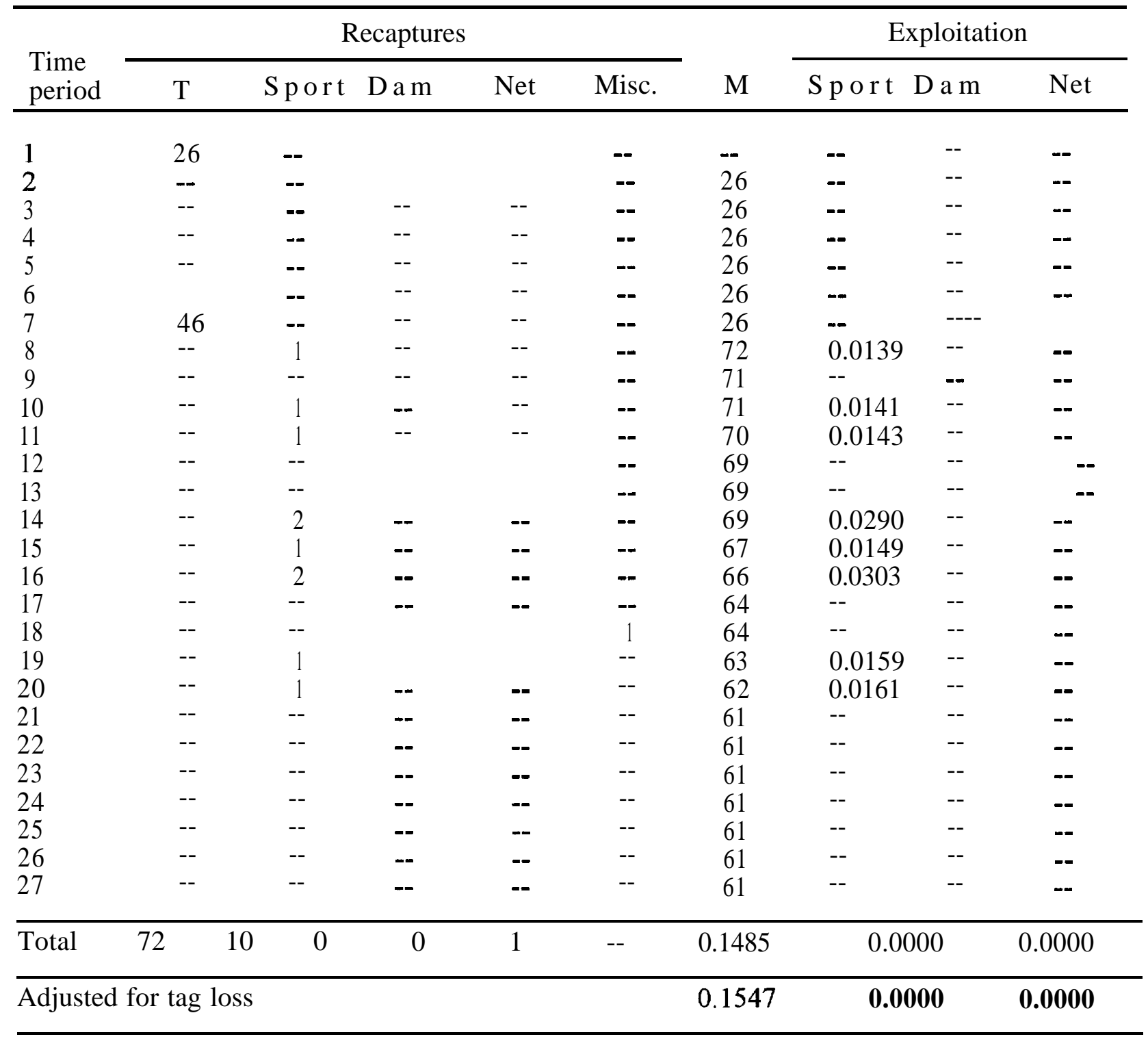


Appendix Table A-9. Exploitation of northern squawfish in John Day Reservoir in 1996. $\quad \mathrm{T}=$ number of fish tagged. $\mathrm{M}=$ number of tagged fish at large. Misc. $=$ tagged fish recaptured outside the program area or fisheries.

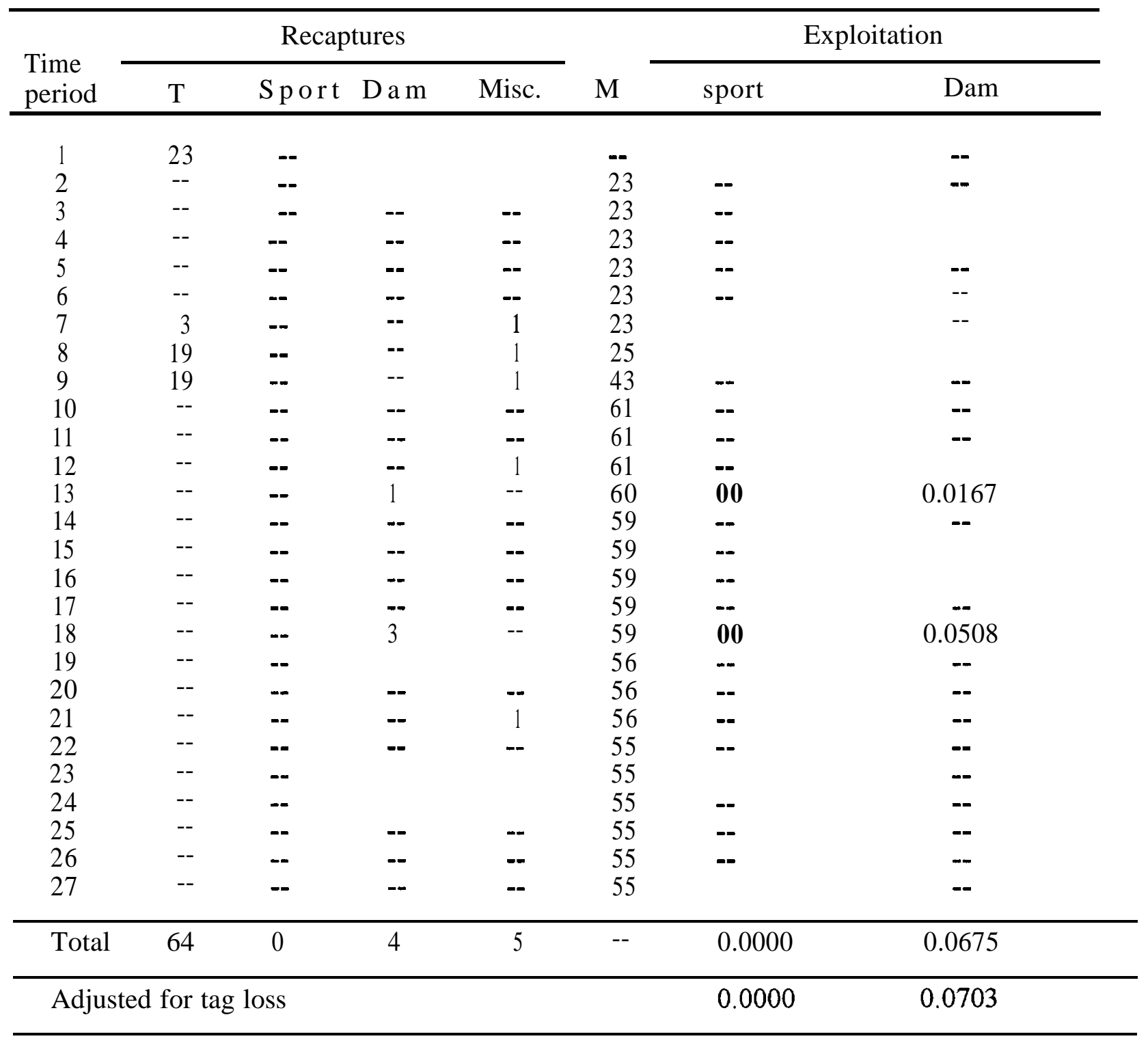


Appendix Table A-10. Exploitation of northern squawfish in McNary Reservoir in 1996. $\mathrm{T}=$ number of fish tagged. $\mathrm{M}=$ number of tagged fish at large. Misc. $=$ tagged fish recaptured outside the program area or fisheries.

\begin{tabular}{|c|c|c|c|c|c|c|c|}
\hline \multirow{2}{*}{$\begin{array}{l}\text { Time } \\
\text { period }\end{array}$} & \multicolumn{4}{|c|}{ Recaptures } & \multirow[b]{2}{*}{ M } & \multicolumn{2}{|c|}{ Exploitation } \\
\hline & $\mathrm{T}$ & Sport & D am & Misc. & & sport & Dam \\
\hline 1 & 4 & -- & -- & -- & - & -- & -- \\
\hline 2 & -- & -- & - & -- & 4 & -- & -- \\
\hline 3 & -- & - & -- & -- & 4 & -- & -- \\
\hline 4 & - & -- & -- & -- & 4 & - & \\
\hline 5 & 104 & -- & -- & - & 4 & -- & \\
\hline 6 & -- & 1 & -- & -- & 108 & 0.0093 & -- \\
\hline 7 & -- & 1 & -- & -- & 107 & 0.0093 & - \\
\hline 8 & -- & -- & -- & -- & 106 & -- & -- \\
\hline 9 & 7 & 1 & -- & -- & 106 & 0.0094 & \\
\hline 10 & 22 & -- & - & -- & 112 & -- & \\
\hline 11 & 18 & -- & -- & -- & 134 & & -- \\
\hline 12 & -- & -- & -- & -- & 152 & & -- \\
\hline 13 & -- & -- & -- & -- & 152 & & -- \\
\hline 14 & -- & -- & -- & -- & 152 & -- & -- \\
\hline 15 & -- & 1 & -- & -- & 152 & 0.0066 & -- \\
\hline 16 & -- & 2 & -- & -- & 151 & 0.0132 & -- \\
\hline 17 & -- & 4 & -- & -- & 149 & 0.0268 & -- \\
\hline 18 & -- & 6 & -- & -- & 145 & 0.0414 & -- \\
\hline 19 & -- & 1 & - & -- & 139 & 0.0072 & \\
\hline 20 & -- & 1 & -- & -- & 138 & 0.0072 & \\
\hline 21 & -- & -- & -- & -- & 137 & -- & -- \\
\hline 22 & -- & 2 & -- & -- & 137 & 0.0146 & - \\
\hline 23 & -- & -- & -- & -- & 135 & -- & -- \\
\hline 24 & -- & 1 & - & -- & 135 & 0.0074 & -- \\
\hline 25 & -- & 1 & -- & -- & 134 & 0.0075 & \\
\hline 26 & -- & 2 & -- & -- & 133 & 0.0150 & \\
\hline 27 & -- & -- & -- & -- & 131 & -- & \\
\hline Total & 155 & 24 & 0 & 0 & -- & 0.1750 & 0.0000 \\
\hline Adjus & r ta & & & & & 0.1824 & 0.0000 \\
\hline
\end{tabular}


Appendix Table A-1 1. Exploitation of northern squawfish in Lower Monumental Reservoir in 1996. $\mathrm{T}=$ number of fish tagged. $\mathrm{M}=$ number of tagged fish at large. Misc.$=$ tagged fish recaptured outside the program area or fisheries.

\begin{tabular}{|c|c|c|c|c|c|c|c|}
\hline \multirow{2}{*}{$\begin{array}{l}\text { Time } \\
\text { period }\end{array}$} & \multicolumn{4}{|c|}{ Recaptures } & \multirow[b]{2}{*}{$\mathrm{M}$} & \multicolumn{2}{|c|}{ Exploitation } \\
\hline & $\mathrm{T}$ & sport & Dam & Misc. & & sport & Dam \\
\hline 1 & & -- & -- & -- & -- & -- & - \\
\hline 2 & & -- & -- & & -- & - & -- \\
\hline 3 & & -- & -- & & -- & -- & -- \\
\hline 4 & - & -- & - & - & & -- & - \\
\hline 5 & -- & - & -- & -- & -- & -- & - \\
\hline 6 & & -- & -- & -- & -- & -- & -- \\
\hline 7 & & & -- & -- & -- & -- & -- \\
\hline 8 & -- & & -- & -- & -- & -- & -- \\
\hline 9 & -- & -- & -- & -- & -- & - & -- \\
\hline 10 & -- & -- & - & -- & -- & -- & -- \\
\hline 11 & 50 & -- & -- & -- & -- & -- & -- \\
\hline 12 & -- & - & -- & -- & 50 & -- & -- \\
\hline 13 & -- & - & -- & -- & 50 & -- & -- \\
\hline 14 & -- & & -- & & 50 & -- & -- \\
\hline 15 & - & -- & - & & 50 & -- & -- \\
\hline 16 & -- & -- & -- & -- & $\mathbf{5 0}$ & -- & - \\
\hline 17 & -- & -- & -- & -- & $\mathbf{5 0}$ & -- & -- \\
\hline 18 & & - & -- & -- & 50 & -- & -- \\
\hline 19 & - & -- & -- & -- & 50 & -- & -- \\
\hline 20 & -- & -- & -- & & 50 & - & -- \\
\hline 21 & - & -- & -- & -- & 50 & -- & - \\
\hline 22 & & -- & -- & -- & 50 & -- & - \\
\hline 23 & & -- & - & -- & 50 & -- & -- \\
\hline 24 & & -- & -- & & 50 & -- & -- \\
\hline 25 & & & -- & -- & 50 & - & -- \\
\hline 26 & & -- & -- & & 50 & $=$ & -- \\
\hline 27 & & -- & -- & -- & 50 & -- & - \\
\hline Total & 50 & 0 & 0 & 0 & -- & 0.0000 & 0.0000 \\
\hline Adjust & 01 & & & & & 0.0000 & 0.0000 \\
\hline
\end{tabular}


Appendix Table A-12. Exploitation of northern squawfish in Little Goose Reservoir in 1996. $\mathrm{T}=$ number of fish tagged. $\mathrm{M}=$ number of tagged fish at large. Misc. $=$ tagged fish recaptured outside the program area or fisheries.

\begin{tabular}{|c|c|c|c|c|c|c|c|}
\hline \multirow{2}{*}{$\begin{array}{l}\text { Time } \\
\text { period }\end{array}$} & \multicolumn{4}{|c|}{ Recaptures } & \multirow[b]{2}{*}{$\mathrm{M}$} & \multicolumn{2}{|c|}{ Exploitation } \\
\hline & $\mathrm{T}$ & Sport & D am & Misc. & & sport & Dam \\
\hline 1 & -- & -- & -- & -- & -- & & - \\
\hline 2 & -- & -- & -- & -- & -- & & -- \\
\hline 3 & -- & -- & - & $=$ & -- & & -- \\
\hline 4 & -- & -- & -- & -- & -- & -- & -- \\
\hline 5 & -- & - & -- & -- & -- & -- & \\
\hline 6 & -- & -- & -- & -- & -- & -- & \\
\hline 7 & -- & -- & - & $m$ & -- & - & -- \\
\hline 8 & -- & -- & -- & -- & -- & & -- \\
\hline 9 & -- & -- & -- & -- & -- & & -- \\
\hline 10 & -- & -- & -- & -- & -- & - & -- \\
\hline 11 & -- & -- & -- & -- & -- & -- & -- \\
\hline 12 & -- & -- & -- & -- & -- & -- & - \\
\hline 13 & 24 & -- & -- & -- & - & & -- \\
\hline 14 & -- & -- & $=$ & -- & 24 & -- & - \\
\hline 15 & -- & - & -- & -- & 24 & & - \\
\hline 16 & -- & -- & -- & -- & 24 & & -- \\
\hline 17 & -- & & & -- & 24 & & -- \\
\hline 18 & -- & 1 & -- & - & 24 & 0.0417 & -- \\
\hline 19 & -- & -- & - & - & 23 & -- & -- \\
\hline 20 & -- & -- & - & -- & 23 & -- & -- \\
\hline 21 & -- & - & $\cdots$ & -- & 23 & -- & $\cdots$ \\
\hline 22 & -- & 1 & -- & -- & 23 & 0.0435 & -- \\
\hline 23 & -- & - & -- & -- & 22 & -- & -- \\
\hline 24 & -- & - & -- & -- & 22 & -- & -- \\
\hline 25 & -- & -- & -- & -- & 22 & -- & \\
\hline 26 & -- & -- & -- & - & 22 & -- & -- \\
\hline 27 & -- & -- & -- & -- & 22 & $-=$ & - \\
\hline Total & 24 & 2 & 0 & 0 & -- & 0.0851 & 0.0000 \\
\hline Adjuste & or ta & & & & & 0.0887 & 0.0000 \\
\hline
\end{tabular}


Appendix Table A-13. Exploitation of northern squawfish in Lower Granite Reservoir in 1996. $\mathrm{T}=$ number of fish tagged. $\mathrm{M}=$ number of tagged fish at large. Misc.$=$ tagged fish recaptured outside the program area or fisheries.

\begin{tabular}{|c|c|c|c|c|c|c|c|}
\hline \multirow{2}{*}{$\begin{array}{l}\text { Time } \\
\text { period }\end{array}$} & \multicolumn{4}{|c|}{ Recaptures } & \multirow[b]{2}{*}{ M } & \multicolumn{2}{|c|}{ Exploitation } \\
\hline & $\mathrm{T}$ & Sport & Dam & Misc. & & sport & Dam \\
\hline 1 & -- & -- & -- & -- & -- & - & \\
\hline 2 & -- & - & - & -- & -- & - & - \\
\hline 3 & -- & - & -- & -- & -- & & \\
\hline 4 & -- & & & -- & -- & & -- \\
\hline 5 & -- & -- & - & -- & -- & -- & -- \\
\hline 6 & 75 & 1 & -- & -- & -- & 0.0133 & -- \\
\hline 7 & -- & -- & -- & -- & 74 & - & \\
\hline 8 & -- & & & -- & 74 & -- & \\
\hline 9 & -- & & & -- & 74 & & -- \\
\hline 10 & -- & -- & -- & -. & 74 & -- & -- \\
\hline 11 & -- & 1 & -- & -- & 74 & 0.0135 & -- \\
\hline 12 & -- & -- & -- & -- & 73 & -- & -- \\
\hline 13 & -- & 1 & -- & -- & 73 & 0.0137 & -- \\
\hline 14 & -- & 1 & -- & -- & 72 & 0.0139 & -- \\
\hline 15 & -- & -- & -- & -- & 71 & -- & -- \\
\hline 16 & -- & 2 & -- & -- & 71 & 0.0282 & \\
\hline 17 & -- & 1 & -- & -- & 69 & 0.0145 & - \\
\hline 18 & -- & -- & -- & -- & 68 & & \\
\hline 19 & -- & & & - & 68 & & \\
\hline 20 & -- & & & -- & 68 & & -- \\
\hline 21 & -- & -- & -- & - & 68 & - & -- \\
\hline 22 & -- & -- & -- & -- & 68 & & -- \\
\hline 23 & -- & -- & -- & -- & 68 & & \\
\hline 24 & -- & 1 & -- & -- & 68 & 0.0147 & -- \\
\hline 25 & -- & & & - & 67 & & -- \\
\hline 26 & -- & & & -- & 67 & -- & - \\
\hline 27 & -- & -- & -- & -- & 67 & -- & \\
\hline Total & 75 & 8 & 0 & 0 & -- & 0.1118 & 0.0000 \\
\hline Adjuste & or ta & & & & & 0.1165 & 0.0000 \\
\hline
\end{tabular}


Appendix Table A-14. Exploitation of northern squawfish systemwide in 1996. T = number of fish tagged. $\mathrm{M}=$ number of tagged fish at large. Misc. = tagged fish recaptured outside the program area or fisheries.

\begin{tabular}{|c|c|c|c|c|c|c|c|c|c|}
\hline \multirow{2}{*}{$\begin{array}{l}\text { Time } \\
\text { period }\end{array}$} & \multicolumn{5}{|c|}{ Recaptures } & \multirow[b]{2}{*}{ M } & \multicolumn{3}{|c|}{ Exploitation } \\
\hline & $\mathrm{T}$ & Sport & Dam & Net & Misc. & & Sport & Dam & Net \\
\hline 1 & 81 & -- & -- & -- & & - & -- & & \\
\hline 2 & 270 & -- & -- & -- & -- & 81 & -- & & \\
\hline 3 & 334 & -- & -- & -- & & 351 & -- & & \\
\hline 4 & 358 & -- & -- & -- & & 685 & -- & -- & -- \\
\hline 5 & 104 & -- & & 2 & -- & 1043 & & -- & 0.0019 \\
\hline 6 & 75 & 6 & & 1 & -- & 1145 & 0.0052 & -- & 0.0009 \\
\hline 7 & 49 & 3 & -- & & 1 & 1213 & 0.0025 & & \\
\hline 8 & 19 & 6 & -- & - & 1 & 1258 & 0.0048 & & \\
\hline 9 & 26 & 4 & -- & -- & -- & 1270 & 0.0031 & - & -- \\
\hline 10 & 22 & 4 & -- & -- & -- & 1292 & 0.0031 & - & -- \\
\hline 11 & 68 & 4 & - & 1 & -- & 1310 & 0.0031 & -- & 0.0008 \\
\hline 12 & -- & 5 & - & 2 & -- & 1373 & 0.0036 & -- & 0.0015 \\
\hline 13 & 24 & 6 & 1 & & & 1366 & 0.0044 & 0.0007 & $7--$ \\
\hline 14 & -- & 13 & - & $=$ & - & 1383 & 0.0094 & -- & -- \\
\hline 15 & -- & 13 & $-m$ & -- & - & 1370 & 0.0095 & & \\
\hline 16 & -- & 20 & -- & -- & 1 & 1357 & 0.0147 & & \\
\hline 17 & -- & 14 & -- & & 1 & 1336 & 0.0105 & -- & -- \\
\hline 18 & -- & 15 & 3 & & -- & 1321 & 0.0114 & 0.0023 & -- \\
\hline 19 & -- & 9 & -- & & 2 & 1303 & 0.0069 & -- & -- \\
\hline 20 & -- & 5 & - & -- & $=$ & 1292 & 0.0039 & -- & -- \\
\hline 21 & -- & 5 & -- & & -- & 1287 & 0.0039 & & \\
\hline 22 & -- & 6 & -- & & -- & 1282 & 0.0047 & & \\
\hline 23 & -- & 1 & -- & & -- & 1276 & 0.0008 & -- & - \\
\hline 24 & -- & 5 & -- & -- & -- & 1275 & 0.0039 & -- & -- \\
\hline 25 & -- & 3 & -- & -- & -- & 1270 & 0.0024 & -- & -- \\
\hline 26 & -- & 3 & -- & -- & -- & 1267 & 0.0024 & -- & -- \\
\hline 27 & -- & 2 & -- & & -- & 1264 & 0.0016 & & \\
\hline Total & 1430 & 152 & 4 & 6 & 6 & -- & 0.1156 & 0.0030 & 0.0050 \\
\hline Adjusted & tag los & & & & & & 0.1205 & 0.0031 & 0.0052 \\
\hline
\end{tabular}




\section{APPENDIX B}

Density, Abundance, Consumption, and Predation Indices for Sampling Locations in the Lower Columbia and Snake Rivers, 1990-96 
Appendix Table B-I. Indices of northern squawfish density from 1990-96 for sampling areas in the lower Columbia and Snake rivers. RKm = river kilometer, BRZ = boat restricted zone.

Density Index (number of electrofishing runs)

\begin{tabular}{lccccccc}
\cline { 2 - 6 } Location, area & 1990 & 1991 & 1992 & 1993 & 1994 & 1995 & 1996 \\
\hline Below & & & & & & & \\
Bonneville Dam & & & & & & & \\
RKm 71-121 & -- & -- & $1.3(68)$ & -- & $1.0(36)$ & $0.9(45)$ & $0.8(43)$ \\
RKm 122-177 & -- & -- & $1.6(65)$ & -- & $1.8(33)$ & $1.4(36)$ & $1.5(35)$ \\
RKm 178-224 & -- & -- & $2.4(64)$ & -- & $1.7(43)$ & $1.1(40)$ & $1.3(40)$ \\
Tailrace & $5.8(26)$ & $6.9(27)$ & $3.4(37)$ & $9.6(16)$ & $2.9(27)$ & $2.3(16)$ & $2.8(24)$ \\
Tailrace BRZ & $13.7(13)$ & $19.0(13)$ & $12.9(23)$ & $14.5(9)$ & $18.9(8)$ & $4.3(8)$ & $5.8(7)$
\end{tabular}

Bonneville Reservoir

Forebay

Mid-reservoir

Tailrace

Tailrace BRZ

The Dalles Reservoir

Forebay

Tailrace

Tailrace BRZ

John Day Reservoir

Forebay

Mid-reservoir

Tailrace

Tailrace BRZ

Lower Monumental Res.

Tailrace

Tailrace BRZ

Little Goose Reservoir

Tailrace

Tailrace BRZ

Lower Granite Reservoir

Upper reservoir

$\begin{array}{lllllll}5.7(47) & -- & -- & 2.2(35) & 2.4(97) & 2.4(79) & 1.3(80) \\ 2.1(52) & -- & -- & 1.2(28) & 0.7(84) & 1.0(45) & 0.7(57) \\ 0.5(37) & -- & -- & 1.1(25) & 0.6(60) & 1.1(80) & 0.8(69) \\ 5.5(15) & -- & -- & 1.5(6) & 6.8(8) & -- & --\end{array}$

\begin{tabular}{rrrclll}
$1.1(62)$ & -- & -- & $1.2(31$ & \multicolumn{2}{c}{$0.6(92) 0.6(62) 0.4(59)$} \\
$2.8(45)$ & -- & -- & $0.7(21)$ & $0.7(40)$ & $1.6(27)$ & $3.7(28)$ \\
$21.5(11)$ & -- & -- & $10.8(5)$ & $5.5(8)$ & $3.5(8)$ & $1.0(3)$
\end{tabular}

$\begin{array}{rcccccc}0.7(56) & 0.7(61) & 1.3(68) & 0.6(44) & 0.7(91) & 0.3(75) & 0.3(54) \\ 0.3(61) & 0.2(58) & 0.3(62) & 0.2(43) & 0.1(43) & 0.1(94) & 0.1(52) \\ 0.8(39) & 0.8(44) & 0.1(47) & 0.5(37) & 0.3(60) & 0.3(80) & 0.5(72) \\ 14.7(16) & 17.9(15) & 9.2(17) & 13.3(9) & 2.4(14) & -- & --\end{array}$

$\begin{array}{lrlllll}-- & 1.5(40) & -- & -- & 0.3(39) & 0.1(38) & 0.2(24) \\ -- & 16.3(16) & -- & -- & 1.2(5) & 3.9(8) & 1.0(8)\end{array}$
$\begin{array}{lrlllll}-- & 1.6(40) & -- & -- & 0.4(31) & 0.1(32) & 0.3(33) \\ -- & 28.3(17) & -- & -- & 6.4(8) & 10.3(8) & 1.0(4)\end{array}$

$\begin{array}{lllllllllll}-- & 1.9(55) & - & - & - & 0.5(85) & 0.2(89) & 0.3(89)\end{array}$ 
Appendix Table B-2. Indices of northern squawfish abundance from 1990-96 for sampling areas in the lower Columbia and Snake rivers. $\mathrm{RKm}=$ river kilometer, $\mathrm{BRZ}=$ boat restricted zone.

\begin{tabular}{|c|c|c|c|c|c|c|c|}
\hline \multirow[b]{2}{*}{ Location, area } & \multicolumn{6}{|c|}{ Abundance Index } & \multirow[b]{2}{*}{1996} \\
\hline & 1990 & 1991 & 1992 & 1993 & 1994 & 1995 & \\
\hline \multicolumn{8}{|l|}{ Below } \\
\hline \multicolumn{8}{|l|}{ Bonneville Dam } \\
\hline RKm 71-121 & -- & -- & 26.8 & -- & 15.4 & 14.5 & 12.2 \\
\hline RKm 122-177 & -- & -- & 19.7 & -- & 26.2 & 17.4 & 18.7 \\
\hline RKm 178-224 & -- & -- & 17.9 & -- & 22.1 & 14.2 & 16.4 \\
\hline Tailrace & 4.5 & 5.4 & 2.7 & 7.6 & 2.3 & 1.8 & 2.2 \\
\hline Tailrace BRZ & 3.0 & 4.1 & 2.8 & 3.1 & 4.1 & 1.0 & 1.3 \\
\hline \multicolumn{8}{|l|}{ Bonneville Reservoir } \\
\hline Forebay & 5.5 & -- & -- & 2.1 & 2.3 & 2.3 & 1.3 \\
\hline Mid-reservoir & 15.2 & -- & -- & 8.5 & 5.0 & 7.4 & 4.9 \\
\hline Tailrace & 0.4 & -- & -- & 0.8 & 0.5 & 0.8 & 0.7 \\
\hline Tailrace BRZ & 0.9 & -- & -- & 0.2 & 1.1 & -- & -- \\
\hline \multicolumn{8}{|l|}{ The Dalles Reservoir } \\
\hline Forebay & 1.4 & -- & -- & 1.6 & 0.7 & 0.5 & 0.6 \\
\hline Tailrace & 2.7 & -- & -- & 0.7 & 0.6 & 1.5 & 3.6 \\
\hline Tailrace BRZ & 4.4 & -- & -- & 2.2 & 1.1 & 0.7 & 0.7 \\
\hline \multicolumn{8}{|l|}{ John Day Reservoir } \\
\hline Forebay & 1.4 & 1.3 & 2.5 & 1.2 & 1.4 & 0.5 & 0.6 \\
\hline Mid-reservoir & 5.2 & 4.7 & 6.6 & 3.2 & 2.3 & 1.0 & 1.1 \\
\hline Tailrace & 1.4 & 1.4 & 0.2 & 0.9 & 0.5 & 0.6 & 1.0 \\
\hline Tailrace BRZ & 1.6 & 1.9 & 1.0 & 1.4 & 0.3 & -- & -- \\
\hline \multicolumn{8}{|c|}{ Lower Monumental Res. } \\
\hline Tailrace & -- & 1.3 & -- & -- & 0.3 & 0.1 & 0.1 \\
\hline Tailrace BRZ & -- & 0.8 & -- & -- & 0.1 & 0.2 & 0.1 \\
\hline \multicolumn{8}{|c|}{ Little Goose Reservoir } \\
\hline Tailrace & -- & 0.7 & -- & -- & 0.2 & $<0.1$ & 0.1 \\
\hline Tailrace BRZ & -- & 1.7 & -- & -- & 0.4 & 0.6 & 0.1 \\
\hline \multicolumn{8}{|c|}{ Lower Granite Reservoir } \\
\hline Upper reservoir & -- & 1.6 & - & -- & 0.5 & 0.2 & 0.2 \\
\hline
\end{tabular}


Appendix Table B-3. Indices of northern squawfish consumption of juvenile salmonids from 1990-96 during spring in the lower Columbia and Snake rivers. RKm = river kilometer, BRZ = boat restricted zone.

Consumption Index (number of digestive tracts examined)

\begin{tabular}{|c|c|c|c|c|c|c|c|}
\hline \multirow{2}{*}{ Location, area } & \\
\hline & 1990 & 1991 & 1992 & 1993 & 1994 & 1995 & 1996 \\
\hline \multicolumn{8}{|l|}{ Below } \\
\hline \multicolumn{8}{|l|}{ Bonneville Dam } \\
\hline RKm 71-121 & -- & -- & $0.5(102)$ & -- & $0.5(14)$ & $0.5(25)$ & $0.4(23)$ \\
\hline RKm 122-177 & -- & -- & $1.0(189)$ & -- & $1.1(34)$ & $0.2(28)$ & $0.1(43)$ \\
\hline RKm 178-224 & -- & -- & $1.1(126)$ & -- & $1.5(42)$ & $0.7(25)$ & $0.4(33)$ \\
\hline Tailrace & $1.2(61)$ & -- & $0.5(22)$ & $0.8(75)$ & $3.2(57)$ & $0.8(25)$ & $0.4(29)$ \\
\hline Tailrace BRZ & $2.7(86)$ & -- & $1.0(77)$ & $1.1(63)$ & $0.6(95)$ & $1.7(17)$ & $0.6(8)$ \\
\hline \multicolumn{8}{|c|}{ Bonneville Reservoir } \\
\hline Forebay & $0.6(153)$ & -- & -- & $0.7(20)$ & $0.2(116)$ & $0.3(88)$ & $0.0(59)$ \\
\hline Mid-reservoir & $0.0(39)$ & -- & & $0.0(14)$ & $0.2(34)$ & $0.0(26)$ & $0.1(17)$ \\
\hline Tailrace & $0.3(7)$ & -- & -- & $0.0(18)$ & $0.0(19)$ & $0.2(22)$ & $0.0(35)$ \\
\hline Tailrace BRZ & $2.3(41)$ & -- & -- & -- & -- & -- & -- \\
\hline \multicolumn{8}{|c|}{ The Dalles Reservoir } \\
\hline Forebay & $0.8(38)$ & -- & & $0.1(19)$ & $0.1(22)$ & $0.0(22)$ & $0.0(15)$ \\
\hline Tailrace & $0.7(27)$ & -- & & $0.0(8)$ & -- & -- & -- \\
\hline Tailrace BRZ & $0.9(50)$ & -- & & $0.0(1)$ & -- & -- & -- \\
\hline \multicolumn{8}{|c|}{ John Day Reservoir } \\
\hline Forebay & $1.5(38)$ & $1.9(23)$ & $1.9(38)$ & $1.5(11$ & 1 ) $1.0(11)$ & $1.7(7)$ & $0.7(4)$ \\
\hline Mid-reservoir & $0.0(6)$ & $0.5(6)$ & $0.0(8)$ & $0.0(2)$ & $0.0(3)$ & $0.0(1)$ & $0.0(3)$ \\
\hline Tailrace & $1.5(17)$ & $0.9(23)$ & $0.0(9)$ & $2.0(24)$ & $0.3(13)$ & $0.8(13)$ & $0.5(14)$ \\
\hline Tailrace BRZ & $2.5(60)$ & $1.5(55)$ & $0.9(35)$ & -- & $0.7(8)$ & -- & -- \\
\hline \multicolumn{8}{|c|}{ Lower Monumental Res. } \\
\hline Tailrace & -- & $0.6(58)-$ & - & -- & $0.7(9)$ & $0.0(2)$ & $0.0(2)$ \\
\hline Tailrace BRZ & -- & $0.7(12.7)$ & -- & -- & -- & $1.3(7)$ & $0.0(1)$ \\
\hline \multicolumn{8}{|c|}{ Little Goose Reservoir } \\
\hline Tailrace & -- & $0.7(68)$ & - & -- & $1.9(12)$ & $1.4(2)$ & $0.7(7)$ \\
\hline Tailrace BRZ & -- & $1.2(126)$ & -- & -- & $1.5(25) \quad 1$ & $1.6(63)-$ & - \\
\hline \multicolumn{8}{|c|}{ Lower Granite Reservoir } \\
\hline Upper-reservoir & -- & $0.3(127)$ & -- & -- & $0.6(41$ & 1) $1.2(16)$ & $0.2(23)$ \\
\hline
\end{tabular}


Appendix Table B-4. Indices of northern squawfish consumption of juvenile salmonids from 1990-96 during summer in the lower Columbia River. $\mathrm{RKm}=$ river kilometer, $\mathrm{BRZ}=$ boat restricted zone.

\begin{tabular}{|c|c|c|c|c|c|c|c|}
\hline \multirow[b]{2}{*}{ Location, area } & \multicolumn{7}{|c|}{ Consumption Index (number of digestive tracts examined) } \\
\hline & 1990 & 1991 & 1992 & 1993 & 1994 & 1995 & 1996 \\
\hline \multicolumn{8}{|l|}{ Below } \\
\hline \multicolumn{8}{|l|}{ Bonneville Dam } \\
\hline RKm 71-121 & -- & -- & $0.3(117)$ & - & $1.8(22$ & ) $1.5(14)$ & $0.0(9)$ \\
\hline RKm 122-177 & -- & -- & $1.3(136)-$ & - & $1.5(32)$ & $0.4(22)$ & $0.0(9)$ \\
\hline RKm 178-224 & -- & -- & $1.9(59)$ & -- & $0.4(32$ & ) $1.2(20)$ & $0.0(20)$ \\
\hline Tailrace & $0.5(45)$ & -- & $2.1(43)$ & $1.2(81)$ & $0.4(24) 0.9$ & $\left(\begin{array}{lll}1 & 1\end{array}\right)$ & $0.6(38)$ \\
\hline Tailrace BRZ & $5.5(109)$ & -- & $7.8(147)$ & $1.0(131)$ & $2.1(56)$ & $1.3(16)$ & $3.1(33)$ \\
\hline \multicolumn{8}{|c|}{ Bonneville Reservoir } \\
\hline Forebay & $1.8(139)$ & -- & -- & $0.5(95)$ & $0.3(111)$ & $0.0(96)$ & $0.3(44)$ \\
\hline Mid-reservoir & $0.0(42)$ & -- & -- & $0.0(31$ & ) & $0.0(24) \quad 0.0$ & $0(19) \quad 0.0(21)$ \\
\hline Tailrace & $0.0(4)$ & -- & -- & $0.0(14)$ & $0.0(15)$ & $0.8(67)$ & $0.0(23)$ \\
\hline Tailrace BRZ & $0.8(61)$ & -- & -- & $1.0(23)$ & $3.2(54)$ & -- & -- \\
\hline \multicolumn{8}{|c|}{ The Dalles Reservoir } \\
\hline Forebay & $1.0(61)$ & -- & -- & $0.0(28)$ & $0.0(27)$ & $0.0(15)$ & $0.0(8)$ \\
\hline Tailrace & $0.0(46)$ & -- & -- & $0.0(9)$ & $0.8(27)$ & $0.0(41)$ & $0.7(92)$ \\
\hline Tailrace BRZ & $6.4(50)$ & -- & -- & $0.5(117)$ & $1.2(43)$ & $2.2(28)$ & $5.4(3)$ \\
\hline \multicolumn{8}{|c|}{ John Day Reservoir } \\
\hline Forebay & $2.4(16)$ & $3.1(17)$ & $0.7(27)$ & $0.6(40)$ & $1.2(57)$ & $2.0(13)$ & $0.4(13)$ \\
\hline Mid-reservoir & $0.9(7)$ & $0.0(3)$ & $0.0(13)$ & $0.6(10)$ & $0.6(5)$ & $0.0(4)$ & $0.0(0)$ \\
\hline Tailrace & $2.6(25)$ & $0.0(19)$ & $0.0(1)$ & $0.0(11)$ & $0.0(4)$ & $0.6(13)$ & $0.3(19)$ \\
\hline Tailrace BRZ & $11.7(50)$ & $2.8(77)$ & $4.6(67) 0.6$ & $6(119) 1.9($ & $(31)-$ & - & -- \\
\hline
\end{tabular}


Appendix Table B-5. Indices of northern squawfish predation of juvenile salmonids from 1990-96 during spring in the lower Columbia and Snake rivers. $\mathrm{RKm}=$ river kilometer, $\mathrm{BRZ}=$ boat restricted zone.

\begin{tabular}{|c|c|c|c|c|c|c|c|}
\hline \multirow[b]{2}{*}{ Location, area } & \multicolumn{7}{|c|}{ Predation Index } \\
\hline & 1990 & 1991 & 1992 & 1993 & 1994 & 1995 & 1996 \\
\hline \multicolumn{8}{|l|}{ Below } \\
\hline \multicolumn{8}{|l|}{ Bonneville Dam } \\
\hline RKm 71-121 & -- & -- & 10.1 & - & 8.0 & 7.3 & 4.9 \\
\hline RKm 122-177 & -- & $-\infty$ & 20.5 & - & 25.5 & 3.5 & 1.9 \\
\hline RKm 178-224 & -- & -- & 33.4 & -- & 33.2 & 9.9 & 6.6 \\
\hline Tailrace & 5.5 & -- & 1.4 & 6.1 & 7.4 & 1.4 & 0.9 \\
\hline Tailrace BRZ & 8.0 & -- & 2.8 & 3.5 & 2.5 & 1.7 & 0.8 \\
\hline \multicolumn{8}{|l|}{ Bonneville Reservoir } \\
\hline Forebay & 3.3 & -- & -- & 1.5 & 0.3 & 0.7 & 0.0 \\
\hline Mid-reservoir & 0.0 & -- & -- & 0.0 & 1.0 & 0.0 & 0.5 \\
\hline Tailrace & 0.1 & -- & -- & 0.0 & 0.0 & 0.2 & 0.0 \\
\hline Tailrace BRZ & 2.0 & -- & -- & -- & -- & 1.5 & -- \\
\hline \multicolumn{8}{|l|}{ The Dalles Reservoir } \\
\hline Forebay & 1.1 & -- & -- & 0.2 & 0.1 & 0.0 & 0.0 \\
\hline Tailrace & 1.9 & -- & -- & 0.0 & -- & -- & -- \\
\hline Tailrace BRZ & 3.9 & -- & -- & 0.0 & -- & -- & -- \\
\hline \multicolumn{8}{|l|}{ John Day Reservoir } \\
\hline Forebay & 2.1 & 2.4 & 4.7 & 1.9 & 1.3 & 0.9 & 0.4 \\
\hline Mid-reservoir & 0.0 & 2.4 & 0.0 & 0.0 & 0.0 & 0.0 & 0.0 \\
\hline Tailrace & 1.9 & 1.3 & 1.9 & 1.7 & 0.2 & 0.5 & 0.3 \\
\hline Tailrace BRZ & 3.9 & 2.9 & 0.9 & -- & 0.2 & -- & -- \\
\hline \multicolumn{8}{|c|}{ Lower Monumental Res. } \\
\hline Tailrace & -- & 0.8 & -- & -- & 0.2 & 0.0 & 0.0 \\
\hline Tailrace BRZ & -- & 0.6 & -- & -- & -- & 0.3 & 0.0 \\
\hline \multicolumn{8}{|c|}{ Little Goose Reservoir } \\
\hline Tailrace & -- & 0.5 & -- & -- & 0.4 & $<0.1$ & 0.1 \\
\hline Tailrace BRZ & -- & 2.0 & -- & -- & 0.6 & 1.0 & -- \\
\hline \multicolumn{8}{|c|}{ Lower Granite Reservoir } \\
\hline Upper-reservoir & -- & 0.5 & -- & -- & 0.3 & 0.2 & 0.1 \\
\hline
\end{tabular}


Appendix Table B-6. Indices of northern squawfish predation of juvenile salmonids from 1990-96 during summer in the lower Columbia River. RKm = river kilometer, BRZ = boat restricted zone.

\begin{tabular}{|c|c|c|c|c|c|c|c|}
\hline \multirow[b]{2}{*}{ Location, area } & \multicolumn{7}{|c|}{ Predation Index } \\
\hline & 1990 & 1991 & 1992 & 1993 & 1994 & 1995 & 1996 \\
\hline \multicolumn{8}{|l|}{ Below } \\
\hline \multicolumn{8}{|l|}{ Bonneville Dam } \\
\hline RKm 71-121 & -- & -- & 6.0 & -- & 27.3 & 14.5 & 0.0 \\
\hline RKm 122-177 & -- & -- & 26.6 & -- & 34.8 & 7.0 & $\mathbf{0 . 0}$ \\
\hline RKm 178-224 & -- & -- & 37.8 & -- & 9.5 & 17.0 & $\mathbf{0 . 0}$ \\
\hline Tailrace & 2.3 & -- & 5.7 & 9.1 & 1.0 & 1.6 & 1.3 \\
\hline Tailrace BRZ & 16.4 & -- & 21.8 & 3.2 & 1.3 & 1.2 & 4.0 \\
\hline \multicolumn{8}{|c|}{ Bonneville Reservoir } \\
\hline Forebay & 9.9 & -- & -- & 1.1 & 0.6 & 0.0 & 0.4 \\
\hline Mid-reservoir & 0.0 & -- & -- & 0.0 & 0.0 & 0.0 & 0.0 \\
\hline Tailrace & 0.0 & -- & -- & 0.0 & 0.0 & 0.6 & 0.0 \\
\hline Tailrace BRZ & 0.7 & -- & -- & 0.2 & 3.5 & -- & -- \\
\hline \multicolumn{8}{|c|}{ The Dalles Reservoir } \\
\hline Forebay & 1.4 & -- & -- & 0.0 & 0.0 & 0.0 & 0.0 \\
\hline Tailrace & 0.0 & -- & -- & 0.0 & 0.5 & 0.0 & 2.5 \\
\hline Tailrace BRZ & 27.8 & -- & -- & 1.1 & 1.4 & 1.5 & 3.8 \\
\hline \multicolumn{8}{|c|}{ John Day Reservoir } \\
\hline Forebay & 3.4 & 4.0 & 1.7 & 0.8 & 1.6 & 1.0 & 0.2 \\
\hline Mid-reservoir & 4.7 & -- & 0.0 & 2.0 & 1.4 & 0.0 & 0.0 \\
\hline Tailrace & 3.8 & -- & 0.0 & 0.0 & 0.0 & 0.4 & 0.2 \\
\hline Tailrace BRZ & 18.6 & 5.4 & 4.6 & 0.9 & 0.5 & -- & -- \\
\hline
\end{tabular}




\begin{abstract}
APPENDIX C
Timing of 1996 Consumption Index Sampling in Relation to Juvenile Salmonid Passage Indices at Lower Columbia and Snake River Dams
\end{abstract}




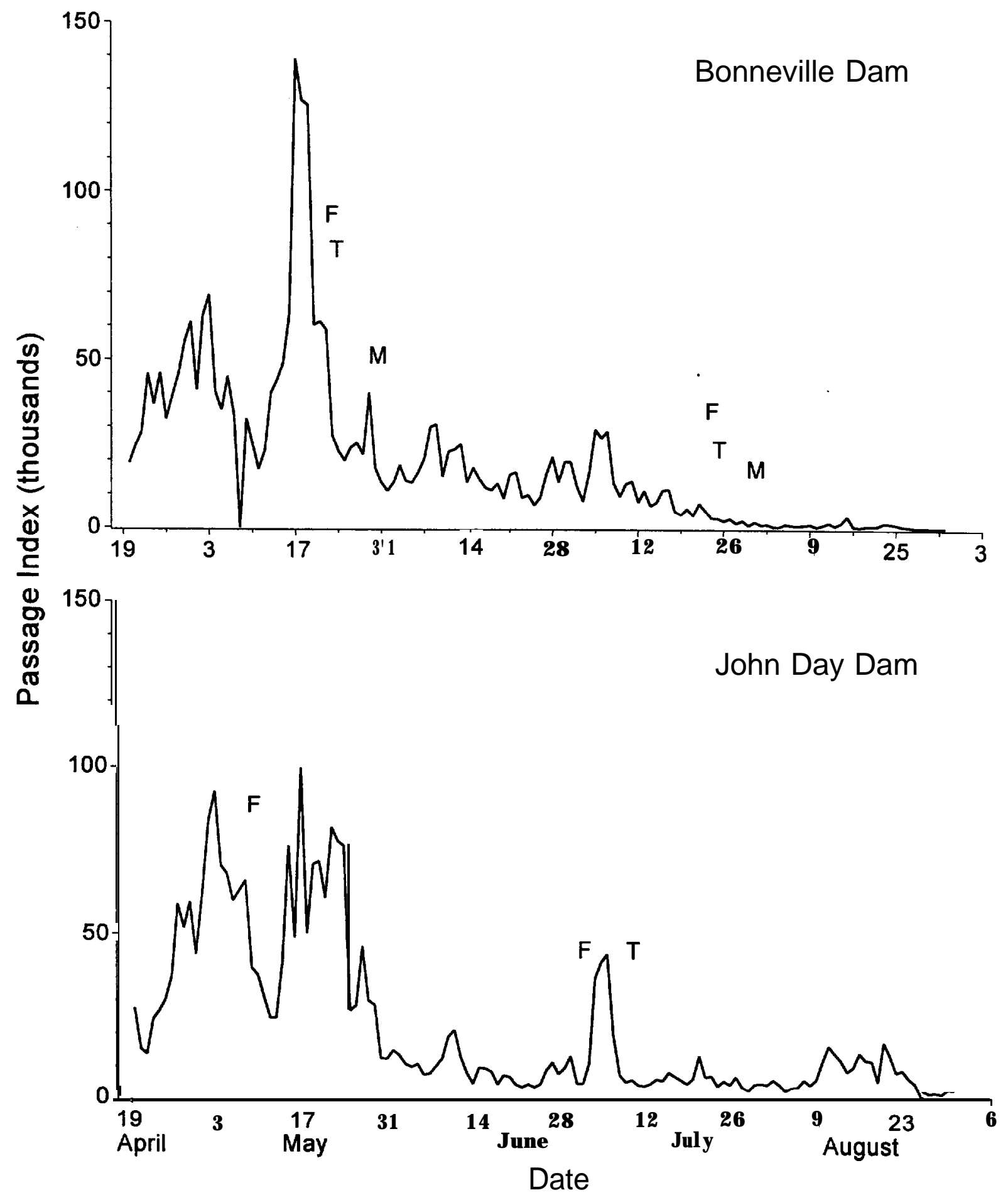

Appendix Table C-l. Timing of consumption index sampling with respect to juvenile salmonid passage indices at Bonneville and John Day dams in 1996. Sample times for forebay (F), tailrace $(\mathrm{T})$, and areas downstream from Bonneville Dam tailrace (M) are shown. 


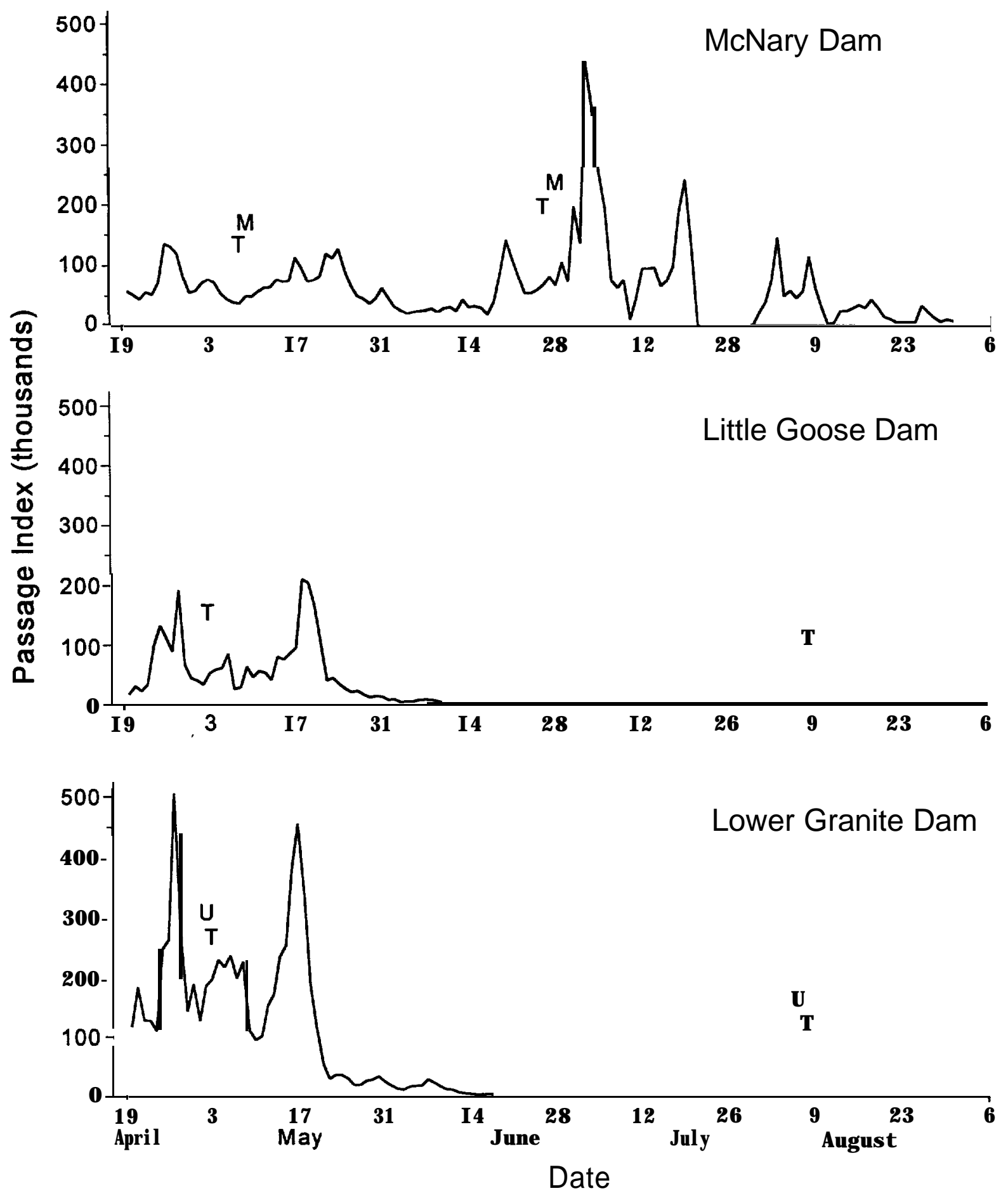

Appendix Table C-2. Timing of consumption index sampling with respect to juvenile salmonid passage indices at McNary, Little Goose, and Lower Granite dams in 1996. Sample times for tailraces (T), mid-reservoir areas of McNary Reservoir (M), and upper Lower Granite Reservoir (U) are shown. 


\section{APPENDIX D}

Digestive Tract Contents and Comparison of Fish Diets of Northern Squawfish, Smallmouth Bass, and Walleye in 1996 
We examined digestive tract contents of 665 northern squawfish, 870 smallmouth bass, and 112 walleye collected during standardized electrofishing in 1996 (Appendix Table D-l). The systemwide frequency of occurrence $(\% \mathrm{FO})$ of salmonids in digestive tracts was $6.9 \%$ in northern squawfish and $0.8 \%$ in smallmouth bass, or approximately $50 \%$ lower than in 1994-95 (Zimmerman et al. in press). The $\%$ FO of salmonids in walleye was $5.2 \%$. The $\% \mathrm{FO}$ of salmonids in northern squawfish was highest in Bonneville Dam tailrace during both spring $(18.9 \%)$ and summer $(19.7 \%)$. Frequency of occurrence of salmonids in smallmouth bass from all Snake River locations during spring was 3.2\%. During summer, the \%FO of salmonids in smallmouth bass was greatest below Bonneville Dam tailrace (2.7\%) and in John Day Reservoir (1.7\%). Systemwide \%FO of salmonids in walleye was higher during spring (8.0\%) than summer $(1.6 \%)$.

The composition of prey fishes (by family) found in northern squawfish and smallmouth bass in 1996 was generally similar to 1994-95 (Zimmerman et al. in press). Salmonids comprised the majority (43-83\%) of prey fish consumed by northern squawfish, whereas sculpins (Cottus spp.) comprised the majority (62-86\%) consumed by smallmouth bass (Appendix Table D-2). The proportion of salmonids found in both northern squawfish and smallmouth bass was greatest in the Snake River. Smallmouth bass utilized prey other than salmonids and sculpins to a far greater extent than northern squawfish, with cyprinids making up the largest proportion of other prey taxa in all three reaches. The proportion of salmonids declined and the proportion of sculpins increased in the diets of northern squawfish and smallmouth bass in 1996. The most common prey fishes utilized by walleye were cyprinids and sandrollers Percopsis transmontana. Salmonids comprised a greater proportion of the diets of walleye than of smallmouth bass. No salmonids were found in walleye stomachs downstream from Bonneville Dam; this is probably attributable to a small sample size. Total number of prey fish per predator (all areas combined) was highest (0.59) for walleye, followed by 0.23 prey fish per smallmouth bass and 0.18 prey fish per northern squawfish. Number of prey consumed per predator in 1996 was 33-46\% lower than 1994-95 for smallmouth bass and northern squawfish. 
Appendix Table D-l. Number of northern squawfish, smallmouth bass, and walleye digestive tracts examined (N) from the lower Columbia and Snake rivers in 1996 that contained food, fish, and juvenile salmonids (Sal).

\begin{tabular}{|c|c|c|c|c|c|c|c|c|c|c|c|c|}
\hline \multirow{2}{*}{$\begin{array}{l}\text { Period: } \\
\text { or area }\end{array}$} & \multicolumn{4}{|c|}{ Northern squawfish } & \multicolumn{4}{|c|}{ Smallmouth bass } & & \multicolumn{2}{|c|}{ Walleye } & \multirow{2}{*}{ keservoir } \\
\hline & Fish & Sal N & Food & Fish & Sal & $\mathrm{N} \quad \mathrm{F}$ & Food & Fish & Sal & & & \\
\hline \multicolumn{13}{|l|}{ Spring: } \\
\hline \multicolumn{13}{|l|}{ Below Bonneville } \\
\hline Dam tailrace & 99 & 43 & 18 & 8 & 39 & 19 & 6 & $\mathbf{0}$ & 2 & 2 & 2 & $\mathbf{0}$ \\
\hline \multicolumn{13}{|l|}{ Bonneville Dam } \\
\hline tailrace & 37 & 15 & 10 & 7 & 6 & 5 & 4 & $\mathbf{0}$ & 8 & 5 & 4 & $\mathbf{0}$ \\
\hline Bonneville & 111 & 41 & 10 & 1 & 174 & 120 & 36 & 0 & 10 & 1 & 1 & $\mathbf{0}$ \\
\hline The Dalles & 15 & 7 & 0 & 0 & 100 & 81 & 27 & $\mathbf{0}$ & 4 & 3 & 3 & 2 \\
\hline John Day & 21 & 9 & 2 & 3 & 111 & 84 & 16 & $\mathbf{0}$ & 26 & 10 & 8 & 2 \\
\hline Lower Mon. & 3 & 2 & 2 & 0 & 6 & 5 & 4 & $\mathbf{0}$ & 0 & -- & -- & -- \\
\hline Little Goose & 7 & 6 & 4 & 4 & 35 & 30 & 13 & 1 & 0 & -- & -- & -- \\
\hline Lower Granite & 23 & 16 & 4 & 3 & 83 & 54 & 10 & 3 & 0 & -- & -- & -- \\
\hline \multicolumn{13}{|l|}{ Summer: } \\
\hline \multicolumn{13}{|l|}{ Below Bonneville } \\
\hline Dam tailrace & 38 & 7 & 2 & 0 & 13 & 8 & 6 & 1 & 1 & 1 & 1 & 0 \\
\hline \multicolumn{13}{|l|}{ Bonneville Dam } \\
\hline tailrace & 71 & 26 & 19 & 14 & 7 & 4 & 3 & 0 & 5 & 3 & 2 & 0 \\
\hline Bonneville & 88 & 27 & 3 & 0 & 56 & 35 & 12 & 0 & 5 & 4 & 4 & 0 \\
\hline The Dalles & 103 & 20 & 7 & 4 & 55 & 40 & 11 & 0 & 20 & 8 & 7 & 0 \\
\hline John Day & 32 & 15 & 2 & 2 & 115 & 89 & 21 & 2 & 31 & 21 & 21 & 1 \\
\hline Lower Mon. & 9 & 2 & 1 & 0 & 24 & 18 & 4 & 0 & 0 & -- & -- & -- \\
\hline Little Goose & 6 & 1 & 0 & 0 & 20 & 13 & 2 & 0 & 0 & -- & -- & -- \\
\hline Lower Granite & 3 & 2 & 0 & 0 & 26 & 18 & 7 & 0 & 0 & -- & -- & -- \\
\hline
\end{tabular}


Appendix Table D-2. Sample size and percentage of salmonids, cottids, and other fish families in northern squawfish, smallmouth bass, and walleye digestive tracts containing identifiable fish in three reaches of the lower Columbia and Snake rivers in 1996. Reaches are downstream from Bonneville Dam (DBD), lower Columbia River reservoirs (COL), and lower Snake River reservoirs (SNK).

\begin{tabular}{|c|c|c|c|c|c|c|c|c|c|}
\hline \multirow{2}{*}{$\begin{array}{l}\text { Sample size, } \\
\text { DBD }\end{array}$} & \multicolumn{3}{|c|}{ Northern squawfish } & \multicolumn{3}{|c|}{ Smallmouth bass } & \multicolumn{3}{|c|}{$\begin{array}{l}\text { Walleye } \\
\text { familv }\end{array}$} \\
\hline & $\mathrm{COL}$ & SNK & D B D & $\mathrm{COL}$ & SNK & $\mathrm{DBD}$ & COL & SNK & \\
\hline Digestive tracts & 246 & 370 & 50 & 65 & 611 & 194 & 16 & 96 & $\mathbf{0}$ \\
\hline Total fish & 64 & 37 & 16 & 21 & 134 & 41 & 9 & 57 & -- \\
\hline Identifiable fish & 57 & 30 & 12 & 16 & 85 & 35 & 5 & 38 & -- \\
\hline$\%$ Salmonidae & 63.2 & 43.3 & 83.3 & 6.2 & 3.5 & 11.4 & 0 & 13.2 & -- \\
\hline$\%$ Cottidae & 26.3 & 56.7 & 16.7 & 62.5 & 85.9 & 48.6 & 20.0 & 42.1 & -- \\
\hline$\%$ Other taxa & 10.5 & 0 & 0 & 31.3 & 10.6 & 40.0 & 80.0 & 44.7 & -- \\
\hline$\%$ Cyprinidae & 1.8 & -- & -- & 12.5 & 3.5 & 20.0 & 40.0 & 23.7 & -- \\
\hline$\%$ Catostomidae & 3.5 & -- & -- & 6.2 & 0 & 2.9 & 0 & 2.6 & -- \\
\hline$\%$ Ictaluridae & 0 & -- & -- & 0 & 1.2 & 17.1 & $\mathbf{0}$ & $\mathbf{0}$ & -- \\
\hline$\%$ Percopsidae & 5.3 & -- & -- & 6.2 & 3.5 & 0 & 40.0 & 3.5 & -- \\
\hline$\%$ Gasterosteidae & 0 & -- & -- & 0 & 0 & 0 & $\mathbf{0}$ & $\mathbf{0}$ & -- \\
\hline$\%$ Centrarchidae & 0 & -- & -- & 0 & 1.2 & 0 & $\mathbf{0}$ & $\mathbf{0}$ & -- \\
\hline$\%$ Percidae & 0 & -- & -- & 6.2 & 1.2 & 0 & $\mathbf{0}$ & $\mathbf{0}$ & -- \\
\hline
\end{tabular}




\section{REFERENCE}

Zimmerman, M.P., D.L. Ward, T.A. Friesen, and C.J. Knutsen. In press. Development of a system-wide predator control program: Indexing and fisheries evaluation. Oregon

Department of Fish and Wildlife, Contract number DE-AI79-90BP07084 1995 Annual Report to the Bonneville Power Administration, Portland, Oregon. 